
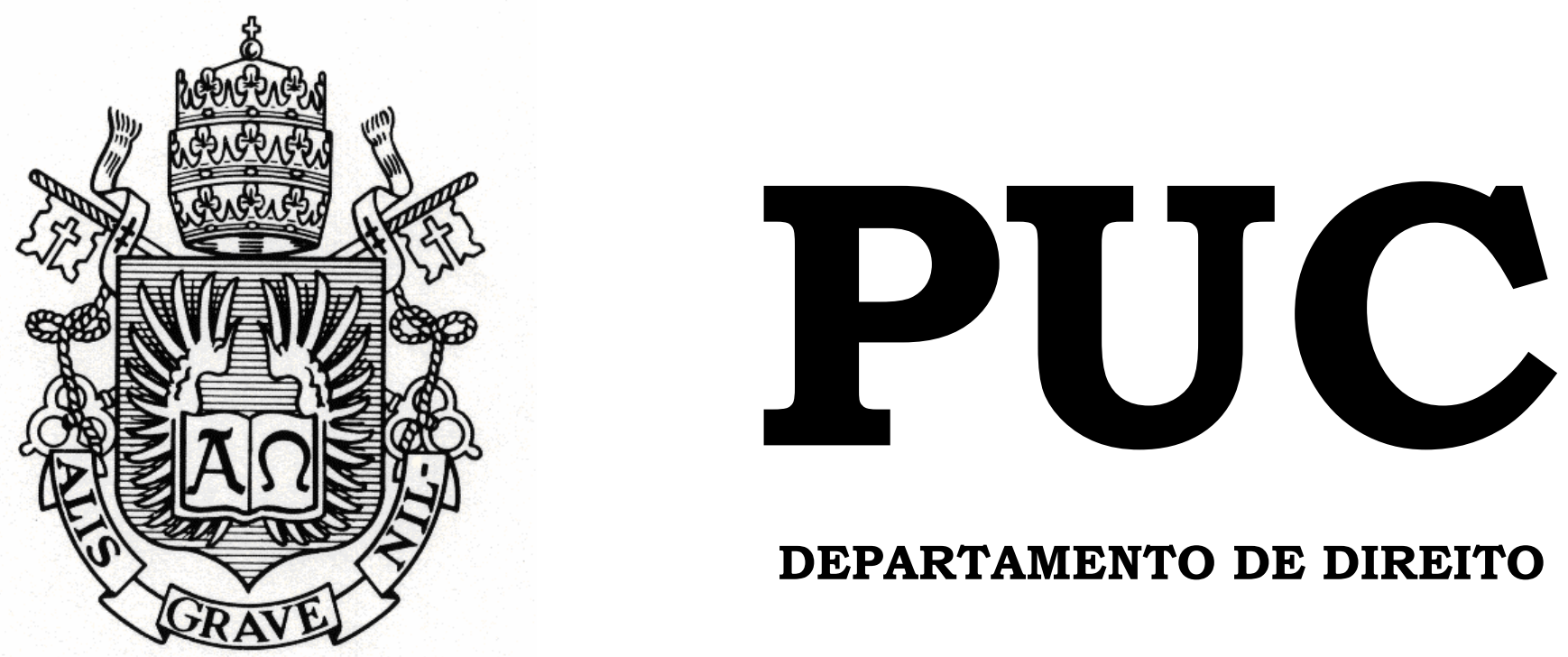

DEPARTAMENTO DE DIREITO

A ISENÇÃO DA COFINS EM PROL DAS SOCIEDADES CIVIS DE PRESTAÇÃO DE SERVIÇOS RELATIVOS À PROFISSÃO LEGALMENTE REGULAMENTADA E A AUSÊNCIA DE COMPETÊNCIA DO STF PARA JULGAMENTO DA MATÉRIA

por

RAPHAEL AGUIAR MIHALIUC

ORIENTADOR: CARLOS HENRIQUE TRANJAN BECHARA 2005.1

PONTIFÍCIA UNIVERSIDADE CATÓLICA DO RIO DE JANEIRO

RUA MARQUÊS DE SÃO VICENTE, 225 - CEP 22453-900 


\title{
A ISENÇÃO DA COFINS EM PROL DAS SOCIEDADES CIVIS DE PRESTAÇÃO DE SERVIÇOS RELATIVOS À PROFISSÃ̃O LEGALMENTE REGULAMENTADA E A AUSÊNCIA DE COMPETÊNCIA DO STF PARA JULGAMENTO DA MATÉRIA
}

\author{
por \\ RAPHAEL AGUIAR MIHALIUC
}

Monografia

apresentada

ao

Departamento de Direito da Pontificia Universidade Católica do Rio de Janeiro (PUC-Rio) para a obtenção do Titulo de Bacharel em Direito.

Orientador: Carlos Henrique Tranjan Bechara 
In Memorian.

Dedico este trabalho ao meu pai, que mesmo não estando mais ao meu lado, continua e continuará sempre representando para mim um exemplo de caráter, honestidade e também de uma rara capacidade de trabalho e realização mesmo diante dos males e das adversidades que a vida normalmente costuma impor. 
Agradeço à Deus por nunca ter perdido a fé, mesmo nos momentos mais difíceis, e pela capacidade em transformar os obstáculos em estímulo na busca pela perfeição. 


\section{RESUMO}

A presente monografia tem como objetivo analisar a ausência de competência do Supremo Tribunal Federal para julgar casos em que se questiona a isenção da COFINS em prol das sociedades civis de profissão legalmente regulamentada, matéria esta de exclusiva competência do Superior Tribunal de Justiça, que se posiciona no sentido da efetiva vigência do benefício em questão, havendo, inclusive, editado Súmula.

Palavras-chave: COFINS, Isenção, Sociedades Civis Prestadoras de Serviços, Competência, Súmula $n .^{\circ} 276$ do STJ. 


\section{SUMÁRIO}

INTRODUÇÃO

\section{CAPÍTULO I}

Aspectos Fundamentais da Cofins e a Evolução Histórica da

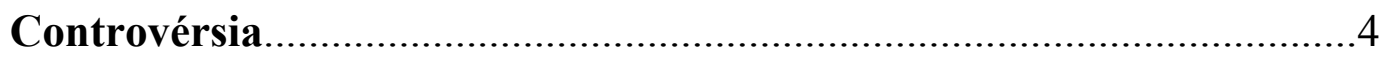

\section{CAPÍTULO II}

Lei Complementar e Lei Ordinária: Aspectos Material e Formal. 11

\section{CAPÍTULO III}

Os Efeitos da Decisão Proferida nos Autos da Ação Declaratória de

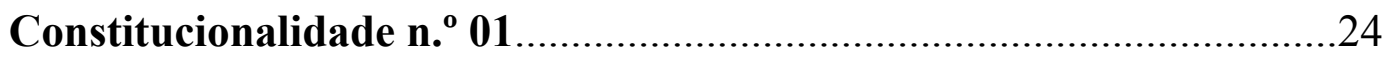

1. O Objeto do Processo e os Limites Objetivos da Coisa Julgada..............24

2. A Afirmação de que a Lei Complementar n. ${ }^{\circ} 70 / 91$ é Materialmente Ordinária Não Possui Efeito Vinculante .28

\section{CAPÍTULO IV}

A Competência Para Julgamento de Conflitos Entre Lei

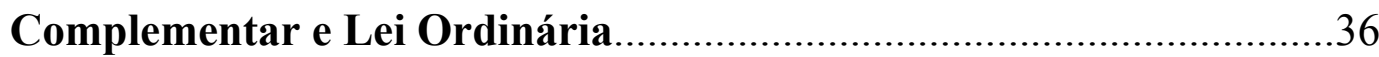

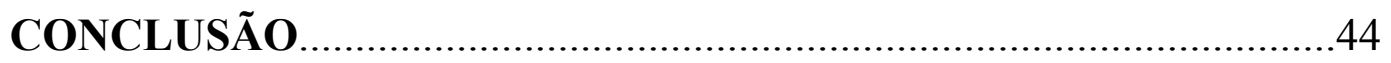

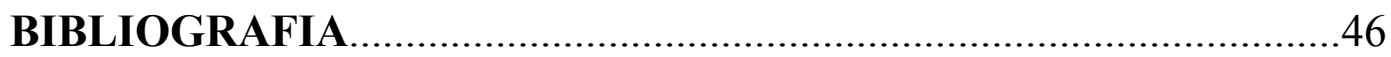




\title{
INTRODUÇÃO
}

\begin{abstract}
"Os Impostos são pagos com o suor de cada homem que trabalha. Se tais impostos são excessivos, ficam refletidos nas fábricas paradas, nas fazendas vendidas para saldar tributos e nas horas de pessoas famintas vagando pelas ruas e procurando emprego em vão.” (Franklin Delano Roosevelt)
\end{abstract}

Para viver em sociedade, o homem precisou lançar mão de parte de seu poder para viver em harmonia, criando, dessa forma, o Estado, entidade com força superior para fazer valer as regras de conduta.

A fim de alcançar seus objetivos, o Estado precisa obter recursos financeiros e desenvolver atividades para obter, gerir e aplicar tais recursos, razão pela qual utiliza-se da tributação - principal instrumento de arrecadação - para exigir que os seus individuos forneçam as receitas que necessita.

Contudo, a atividade do ente público no nosso país alimenta a tendência de se considerar um fim em si mesmo, desrespeitando, muitas das vezes, as limitações traçadas pela Constituição da República, chegando-se ao ponto absurdo de ser considerado como verdadeiro inimigo da sociedade, destruindo a confiança depositada pelos cidadãos, refletindo, inexoravelmente, na completa falência moral da entidade.

Cobra-se tributos flagrantemente ilegais, abusivos $\mathrm{e}$ inconstitucionais, instituídos de forma espúria, dos quais somente pela via judicial é que se pode ver livre o contribuinte, e somente pelos tortuosos caminhos da repetição de indébito pode reaver o valor pago indevidamente.

Essa é a realidade atual do sistema tributário brasileiro: utilizando-se constantemente da ilegalidade, o Estado institui cobranças abusivas, auferindo receita, pelos meios coercitivos de que dispõe, sem a 
observância dos limites traçados pelo ordenamento jurídico-constitucional, causando o verdadeiro caos social e, quando não muito, a fim de aumentar a arrecadação, utiliza-se de argumentos exclusivamente políticos para que nossa jurisprudência mude o seu posicionamento, acarretando, por conseguinte, a completa insegurança jurídica.

Nesse contexto, o presente trabalho tem o intuito de analisar a ação leviana e silenciosa da Procuradoria da Fazenda Nacional que, utilizando-se de Reclamações e Recursos Extraordinários, procura derrubar o posicionamento já consolidado pelo Egrégio Superior Tribunal de Justiça - materializado na Súmula n. ${ }^{\circ}$ 276, que garante a isenção da Cofins às sociedades profissionais de prestação de serviços relativos à profissão legalmente regulamentada -, levando a matéria à análise do Supremo Tribunal Federal.

Com efeito, uma mudança de posicionamento da matéria em questão acarretará um enorme aumento tributário para tais sociedades, o que causará uma alteração ainda maior no preço final dos serviços consumidos no mercado e, conseqüentemente, um maior prejuízo ao consumidor final, efetivo contribuinte do tributo cobrado pelo fisco.

Assim, no primeiro capítulo demonstraremos as origens da controvérsia relativa à isenção promovida pela Lei Complementar n. ${ }^{\circ} 70 / 91$ e sua revogação pela Lei Ordinária n. $^{\circ}$ 9.430/96, bem como os fatos e fundamentos que deram ensejo à edição da Súmula n. ${ }^{\circ} 276$ do STJ.

No segundo capítulo, manifestaremos o nosso entendimento de que lei complementar é norma superior à lei ordinária, não podendo se sujeitar às mudanças conferidas por esta. 
No terceiro capítulo, será analisado o principal fundamento da Procuradoria da Fazenda Nacional sobre a legítima revogação da Cofins, qual seja, os efeitos da afirmação proferida pelo Ex.mo Sr. Ministro Moreira Alves, nos autos da Ação Declaratória de Constitucionalidade n. ${ }^{\circ}$ 01, de que a Lei Complementar n. ${ }^{\circ}$ 70/91 é materialmente ordinária, podendo ser modificada por lei ordinária.

No quarto capítulo, demonstraremos que eventual conflito entre lei ordinária e lei complementar deve ser dirimido pelo Superior Tribunal de Justiça, uma vez que somente a Lei de Introdução ao Código Civil é que possui dispositivos para o tratamento da matéria. 


\title{
CAPÍTULO I
}

\section{Aspectos Fundamentais da Cofins e a Evolução Histórica da Controvérsia}

Em substituição ao extinto Fundo de Investimento Social (FINSOCIAL), a União Federal, nos termos do artigo 195 da Constituição Federal de 1988, instituiu a chamada Contribuição para o Financiamento da Seguridade Social (COFINS) através da Lei Complementar n. ${ }^{\circ}$ 70/91, tendo como base de cálculo o faturamento mensal das empresas, assim considerada a receita bruta das vendas de mercadorias e serviços.

Nesse contexto, preconizou em seu artigo $6^{\circ}$, inciso II, norma de isenção nos seguintes termos:

\footnotetext{
"Art. $6^{\circ}$. São isentas da contribuição:

I - omissis;

II - as sociedades civis de que trata o artigo $1^{\circ}$ do Decretolei n. ${ }^{\circ} 2.397 / 87 ; "$
}

A supracitada norma, por sua vez, possui a seguinte redação:

\begin{abstract}
“Art. $1^{\circ}$. A partir do exercício financeiro de 1989 , não incidirá o Imposto de Renda das pessoas jurídicas sobre o lucro apurado, no encerramento de cada período-base, pelas sociedades civis de prestação de serviços profissionais relativos ao exercício de profissão legalmente regulamentada, registradas no Registro Civil das Pessoas Jurídicas e constituídas exclusivamente por pessoas físicas domiciliadas no País." (grifos nossos)
\end{abstract}

Verifica-se, portanto, que estariam amparadas pela isenção veiculada na Lei Complementar n. $^{\circ} 70 / 91$ as sociedades civis que preenchessem os requisitos legais previstos no artigo $1^{\circ}$ do Decreto-lei n. $^{\circ}$ 2.397/87, quais sejam: 
a) constituir-se em pessoa jurídica devidamente registrada;

b) ter por objeto a prestação de serviços relacionados à profissão legalmente regulamentada ${ }^{1}$;

c) apresentar em seu quadro societário pessoas físicas domiciliadas no país.

A Fazenda Nacional, contudo, impossibilitando ao máximo o direito preconizado na aludida norma de isenção, adotava uma interpretação restritiva dos dispositivos, alegando, em apertada síntese, que as sociedades somente fariam jus a tal isenção se fossem optantes pelo regime de tributação pelo lucro real.

Diante dessa alegação, que sequer possuía respaldo legal, não restou outra alternativa aos contribuintes senão a de bater às portas do Poder Judiciário através de diversas ações judiciais - mormente mandados de segurança coletivos impetrados pelas Seccionais da Ordem dos Advogados do Brasil em prol das sociedades de advogados sob sua jurisdição $^{2}$ - para pleitear o que lhes foi conferido de forma ampla e expressa.

\footnotetext{
1 Sociedades de médicos, dentistas, veterinários, advogados, contadores, administradores, economistas, publicitários, entre outros.

${ }^{2} \mathrm{OAB} / \mathrm{AL}-\mathrm{MS}$ n. ${ }^{\mathrm{o}}$ 2003.80.00.002930-6 - $1^{\mathrm{a}}$ Vara Federal de Maceió/AL; OAB/CE - MS n. ${ }^{\circ}$ 2001.81.00.018005-1 - $4^{\mathrm{a}}$ Vara Federal de Fortaleza/CE; OAB/ES - MS n. ${ }^{\circ}$ 2003.50.01.001950$6-1^{\text {a }}$ Vara Federal de Vitória/ES; OAB/MA - MS n. ${ }^{\circ}$ 2003.37.00.005435-3 - $5^{\text {a }}$ Vara Federal de São Luís/MA; OAB/PA - MS n. ${ }^{\circ}$ 2002.39.00.00.9962-0 - $5^{\text {a }}$ Vara Federal de Belém/PA; OAB/PE - MS n. ${ }^{\circ}$ 2001.83.00.014525-0 - $3^{\mathrm{a}}$ Vara Federal de Recife/PE; OAB/RJ - MS n. ${ }^{\circ}$

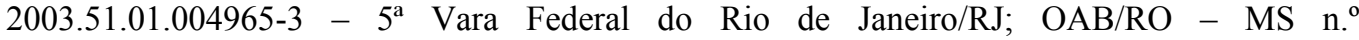
2003.41.00.000320-8 - $3^{\text {a }}$ Vara Federal de Porto Velho/RO; OAB/RS - MS n. ${ }^{\circ}$ 2001.71.00.026831-5 - $6^{\mathrm{a}}$ Vara Federal de Porto Alegre/RS; OAB/SC - MS n. ${ }^{\circ}$ 2003.72.00000106-1 $-1^{\mathrm{a}}$ Vara Federal de Florianópolis/SC; OAB/SP - MS n. ${ }^{\circ}$ 2003.61.00.014084-5 - $21^{\mathrm{a}}$ Vara Federal de São Paulo/SP; OAB/TO - MS n. $^{\circ}$ 2003.43.00.000094-7 - 2 $2^{\mathrm{a}}$ Vara Federal de Palmas/TO.
} 
Quando a matéria, por fim, chegou ao Superior Tribunal de Justiça, consignou aquela egrégia Corte de forma favorável aos contribuintes, no sentido do afastamento da cobrança da COFINS, independente do regime de tributação do imposto de renda escolhido pelas pessoas jurídicas ${ }^{3}$, conforme se verifica nas seguintes ementas:

"EMENTA: Processual Civil e Tributário - Agravo regimental - Cofins - Isenção - Sociedades civis prestadoras de serviços - Precedentes.

1. Agravo regimental interposto contra decisão que, com base no art. 557, $\S 1^{\circ}$, do $\mathrm{CPC}$, deu provimento ao recurso especial ofertado pela parte-agravada.

2. A Lei Complementar n. 70/1991, de 30.12.1991, em seu art. $6^{\circ}$, II, isentou, expressamente, da contribuição da Cofins, as sociedades civis de que trata o art. $1^{\circ}$ do Decreto-Lei $n$. 2.397, de 21.12.1987, sem exigir qualquer outra condição, senão as decorrentes da natureza jurídica das mencionadas entidades.

3. Em conseqüência da mensagem concessiva de isenção contida no art. $6^{\circ}$, II, da Lei Complementar n. $.^{\circ} 70 / 1991$, fixase $o$ entendimento de que a interpretação do referido comando posto em lei complementar, conseqüentemente, com potencialidade hierárquica em patamar superior à legislação ordinária, revela que serão abrangidas pela isenção da Cofins as sociedades civis que, cumulativamente, apresentem os seguintes requisitos:

- sejam sociedades constituídas exclusivamente por pessoas físicas domiciliadas no Brasil;

- tenham por objetivo a prestação de serviços profissionais relativos ao exercício de profissão legalmente regulamentada, e

- estejam registradas no Registro Civil das Pessoas Jurídicas.

4. Outra condição não foi considerada pela lei complementar, no seu art. $6^{\circ}$, II, para o gozo da isenção, especialmente, o tipo de regime tributário adotado para fins de incidência ou não do Imposto de Renda.

5. Posto tal panorama, não há suporte jurídico para se acolher a tese da Fazenda Nacional de que há, também, ao lado dos requisitos acima elencados, um último, o do tipo de regime tributário adotado pela sociedade. A lei complementar não faz tal exigência, pelo que não cabe ao intérprete criá-la.

6. É irrelevante o fato de a recorrente ter optado pela tributacão dos seus resultados com base no lucro presumido, conforme the permite $o$ art. 71 da Lei $n$.

\footnotetext{
${ }^{3}$ Neste mesmo sentido já havia se pronunciado nossa doutrina, sendo oportuno transcrever as seguintes palavras do eminente tributarista Hugo de Brito Machado:

"A isenção instituída pelo art. $6^{\circ}$, II, da Lei Complementar n. ${ }^{\circ}$ 70/1991, não é decorrente do regime de tributação dos rendimentos das sociedades de profissionais, embora tenha os mesmos fundamentos pré-jurídicos da isenção do IR concedida àquelas sociedades.” (MACHADO, Hugo de Brito. Curso de Direito Tributário. $8^{\mathrm{a}}$ ed. Rio de Janeiro: Forense, 1993. p. 151).
} 
8.383/1991, e os arts. $1^{\circ}$ e $2^{\circ}$ da Lei n. 8.541/1992. Essa opção terá reflexos para fins de pagamento do Imposto de renda. Não afeta, porém, a isenção concedida pelo art. $6^{\circ}$, II, da Lei Complementar n. 70/1991, haja vista que esta, repita-se, não colocou como pressuposto para o gozo da isencão o tipo de regime tributário seguido pela sociedade civil.

7. A Revogação da isenção pela Lei n. 9.430/1996 fere, frontalmente, o princípio da hierarquia das leis, visto que tal revogação só poderia ter sido veiculada por outra lei complementar.

8. Agravo regimental não provido." (grifos nossos) (AgRg no REsp n. ${ }^{\circ}$ 422.741/MG; Primeira Turma; Rel. Min. José Delgado; j. 18 jun. 2002)

"EMENTA: Tributário - Cofins - Sociedades civis - Lei Complementar n..$^{\circ}$ 70/1991 - Decreto-lei n. ${ }^{\circ}$ 2.397/1987.

- A circunstância de as sociedades a que se refere o "caput" do art. $1^{\circ}$ do Decreto-lei n. ${ }^{\circ}$ 2.937/1987 haverem optado pelo regime instituído pela Lei $n .^{\circ} 8.541 / 1992$ é irrelevante para que se lhe reconheça a isenção relativa à contribuição 'Cofins'. Tal isenção nada tem a ver com o modo pelo qual as empresas recolhem o Imposto de Renda" (grifos nossos) (REsp n. . 260.960/RS; Primeira Turma; Rel. Min. Humberto Gomes de Barros; j. 13 fev. 2001)

"EMENTA: Processual Civil e Tributário - Cofins Sociedades civis prestadoras de serviços profissionais Isenção - Decisão consoante com precedentes jurisprudenciais do STJ - Negativa de seguimento ao recurso especial - Agravo regimental - Inalterabilidade do 'decisum'.

Mantém-se a decisão monocrática que negou seguimento a recurso especial interposto em confronto com a jurisprudência dominante no âmbito do STJ.

As sociedades civis de prestação de serviços profissionais são beneficiadas com 0 favor isencional previsto pelo artigo $6^{\circ}$, inciso II, da Lei Complementar n. ${ }^{\circ}$ 70/1991, sendo irrelevante que se tenha feito opcão pelo regime

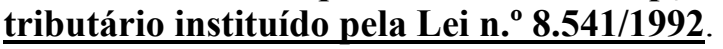

Agravo regimental improvido." (grifos nossos)

(AgRg no REsp n. ${ }^{\circ}$ 422.342/RS; Primeira Turma; Rel. Min. Garcia Vieira; j. 15 ago. 2002)

"EMENTA: Processual Civil e Tributário - Agravo regimental - Recurso especial - Seguimento negado (art. 557 do CPC) - Cofins - Isenção - Sociedades civis - Lei Complementar n. ${ }^{\circ}$ 70/1991, e Decreto-Lei n. ${ }^{\circ}$ 2.397/1987. 
1. Pacificado o entendimento desta Corte no sentido de que as sociedades civis de prestação de serviços são isentas da Cofins, nos termos do art. $6^{\circ}$, II, da Lei Complementar $n .^{\circ}$ 70/1991, sendo irrelevante a circunstância de haverem optado pelo regime instituído pela Lei n. $^{\circ}$ 8.541/1992.

2. Confirmada a decisão monocrática que, nos termos do art. 557 do CPC, negou seguimento ao recurso especial, cuja pretensão era contrária à jurisprudência pacífica desta Corte. 3. Agravo regimental improvido." (grifos nossos)

(AgRg no REsp n. ${ }^{\circ}$ 226.386/PR; Segunda Turma; Rel. Min. Eliana Calmon; j. 13 ago. 2002)

"EMENTA: Tributário - Cofins - Sociedades civis de
prestação de serviços profissicionais - Isenção - Requisitos
essenciais - Regime tributário - Lei n. ${ }^{\circ} 8.541 / 1992-$
Revogação da Lei Complementar n. ${ }^{\circ} 70 / 1991-$
Impossibilidade - Princípio da Hierarquia das leis - Lei n.
9.430/1996 (lei ordinária) - Precedentes.
- A Lei Complementar n. ${ }^{\circ} 70 / 1991$, em seu art. $6^{\circ}$, inc. II,
isentou da Cofins, as sociedades civis de prestação de
serviços de que trata o art. $1^{\circ}$ do Decreto-Lei n. ${ }^{\circ} 2.397$, de 21
de dezembro de 1987 , estabelecendo como condições
somente aquelas decorrentes da natureza jurídica das
referidas sociedades.
- A isenção concedida pela Lei Complementar n. $70 / 1991$
não pode ser revogada pela Lei n. ${ }^{\circ} 9.430 / 1996$, lei ordinária,
em obediência ao princípio da hierarquia das leis. - A opção pelo regime tributário instituído pela Lei n. $^{\circ}$ $8.514 / 1992$ não afeta a isenção concedida pelo art. $6^{\circ}$, II, da Lei Complementar n. $^{0}$ 70/1991. Entre os requisitos elencados como pressupostos ao gozo do benefício não está inserido o tipo de regime tributário adotado pela sociedade para recolhimento do Imposto de Renda.

- Recurso especial não conhecido." (grifos nossos) (REsp n. ${ }^{\circ}$ 221.710/RJ; Segunda Turma; Rel. Min. Eliana Calmon; j. 04 out. 2001)

Destarte, cumprindo o seu papel constitucional de uniformizador de jurisprudência infraconstitucional e consolidando o entendimento pacificado em suas duas Turmas especializadas em direito público, o Superior Tribunal de Justiça editou a Súmula n. ${ }^{\circ}$ 276, que possui o seguinte enunciado:

\footnotetext{
"As sociedades civis de prestação de serviços profissionais são isentas da Cofins, irrelevante o regime tributário adotado."
} 
Diante disso, aquelas sociedades, devidamente enquadradas na

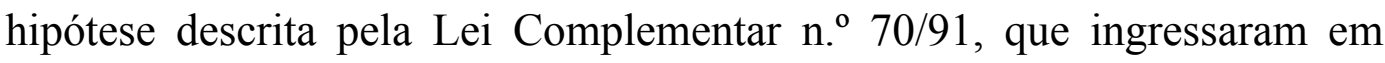
juízo contra a absurda exigência da COFINS, tiveram seu direito à isenção da contribuição reconhecido, podendo, inclusive, requerer a compensação desses valores com parcelas vincendas de outros tributos ou contribuições arrecadados pela Secretaria da Receita Federal.

Contudo, em 30 de dezembro de 1996, foi publicada a Lei Ordinária n. ${ }^{\circ}$ 9.430/96, revogando a supracitada isenção, nos termos do seu artigo 56:

\footnotetext{
"Art. 56. As sociedades civis de prestação de serviços de profissão legalmente regulamentada passam a contribuir para a seguridade social com base na receita bruta da prestação de serviços, observadas as normas da Lei Complementar n. ${ }^{\circ} 70$, de 30 de 1.991."
}

Estabeleceu-se, portanto, mais uma fase na conflituosa relação entre contribuintes e fisco, o que resultou no retorno das sociedades civis de profissão regulamentada à juízo, rogando pela aplicação do princípio da hierarquia das normas, uma vez que uma norma inferior não poderia revogar isenção conferida por lei complementar.

Retornando novamente a matéria a análise do Superior Tribunal de Justiça, consignou aquela Egrégia Corte entendimento favorável aos contribuintes, no sentido da ilegalidade na forma pela qual foi revogada a isenção da COFINS, tendo em vista o princípio da hierarquia das normas, que encontra alicerce na Lei de Introdução ao Código Civil.

Oportuno ressaltar, que na assentada de 09 de outubro de 2003, a Egrégia Primeira Seção, ao julgar o REsp n. ${ }^{\circ}$ 382.736/SC, reexaminou o disposto na Súmula n. ${ }^{\circ}$ 276, decidindo pela manutenção do entendimento ora esposado. 
Irresignada com a orientação da Corte Especial em favor dos contribuintes, a Procuradoria da Fazenda está ajuizando Reclamações perante o Supremo Tribunal Federal, alegando uma suposta usurpação de competência de nossa Corte Constitucional, uma vez que este tribunal, no julgamento da Ação Declaratória de Constitucionalidade n. ${ }^{\circ}$ 01, teria determinado que a Lei Complementar n. ${ }^{\circ}$ 70/91 possui status de lei ordinária.

Todavia, conforme se demonstrará doravante, não há o alegado malferimento, seja porque a competência para julgamento da matéria é do Superior Tribunal de Justiça, seja porque a decisão proferida nos autos da Ação Declaratória de Constitucionalidade n. $^{\circ} 01$ se circunscreveu a declarar a constitucionalidade de determinados dispositivos da Lei Complementar n. ${ }^{\circ}$ 70/91, apenas afirmando, brevemente, que esta lei é materialmente ordinária, o que, de fato, não confere à tal entendimento efeito vinculante, nem tampouco contribui para garantir a validade da contribuição às sociedades em questão. 


\section{CAPÍTULO II}

\section{Lei Complementar e Lei Ordinária: Aspectos Material e Formal}

A constitucionalidade da cobrança da COFINS com base na Lei Complementar n. ${ }^{\circ}$ 70/91, foi reconhecida, conforme sabemos todos, pelo Egrégio Supremo Tribunal Federal, ao julgar, na sessão plenária realizada no dia $1^{\circ}$ de dezembro de 1993, a Ação Declaratória de Constitucionalidade $\mathrm{n}^{\circ} 01$.

Naquela oportunidade, externando suas razões de decidir, assim se manifestou o Ministro Moreira Alves, relator, sobre não ser a instituição de contribuição social - cuja norma-matriz se encontra no inciso I do artigo 195 da Constituição Federal - matéria pertencente ao âmbito restrito das leis complementares:

“(...) a contribuição social em causa, incidente sobre o faturamento dos empregadores, é admitida expressamente pelo inciso I do artigo 195 da Carta Magna, não se podendo pretender, portanto, que a Lei Complementar n. ${ }^{\circ}$ 70/91 tenha criado outra fonte de renda destinada a garantir a manutenção ou a expansão da seguridade social.

Por isso mesmo, essa contribuição poderia ser instituída por Lei Ordinária. A circunstância de ter sido instituída por lei formalmente complementar - a Lei Complementar n. ${ }^{\circ}$ 70/91 - não lhe dá, evidentemente, a natureza de contribuição social nova, a que se aplicaria o disposto no $\S$ $4^{\circ}$ do artigo 195 da Constituição, porquanto essa lei, com relação aos dispositivos concernentes à contribuição social por ela instituída - que são objeto desta ação -, é materialmente ordinária, por não tratar, nesse particular, de matéria reservada, por texto expresso da Constituição, à lei complementar. A jurisprudência dessa Corte, sob o império da Emenda Constitucional n. ${ }^{\circ}$ 1/69 - e a Constituição atual não alterou esse sistema -, se firmou no sentido de que só se exige lei complementar para as matérias para cuja disciplina a Constituição expressamente faz tal exigência, e, se porventura a matéria, disciplinada por lei cujo processo legislativo observado tenha sido o da lei 
complementar, não seja daquelas para que a Carta Magna exige essa modalidade legislativa, os dispositivos que tratam dela se têm como dispositivos de lei ordinária." (grifos nossos)

Infere-se, da leitura do voto supra, que o ponto levantado na discussão da Ação Declaratória de Constitucionalidade n. ${ }^{\circ} 01$ pelo Egrégio Supremo Tribunal Federal causou imensa confusão jurídica ao enunciar que possível a alteração de lei complementar por dispositivo de lei ordinária, desde que a matéria não fosse daquela sob a reserva de lei complementar, e pior, ao reconhecer que a Lei Complementar n. ${ }^{0}$ 70/91 possui status de lei ordinária.

Ora, como é cediço, as leis complementares, desempenham papel de destaque no Sistema Tributário Nacional, sendo-lhes reservado, pela Constituição Federal:

a) dispor sobre conflitos em matéria tributária entre a União, os Estados, o Distrito Federal e os Municípios (artigo 146, inciso I);

b) regular limitações constitucionais ao poder de tributar (artigo 146, inciso II);

c) estabelecer normas gerais em matéria de legislação tributária (artigo 146, inciso III);

d) instituir empréstimos compulsórios (artigo 148);

e) instituir outros impostos que não os previstos expressamente na Constituição - competência residual (artigo 154, inciso I);

f) regular competência para instituições do imposto sobre a transmissão causa mortis e doações (artigo $155, \S 1^{\circ}$, inciso III); 
g) definir os produtos semi-elaborados destinados ao exterior sobre os quais incidirá o ICMS (artigo 155, § $2^{\circ}$, inciso X, alínea 'a');

h) em relação ao ICMS, definir os contribuintes, dispor sobre substituição tributária, disciplinar a compensação do imposto, etc. (artigo $155, \S 2^{\circ}$, inciso XII);

i) definir os serviços sobre os quais incidirá o ISS (artigo 156, inciso IV);

j) fixar as alíquotas máximas do ISS (artigo $156, \S 4^{\circ}$, inciso I);

1) excluir da incidência do ISS a exportação de serviços para o exterior (artigo 156, $\S 4^{\circ}$, inciso II);

m) disciplinar os aspectos previstos no artigo 161, relativos à distribuição das receitas tributárias; e

n) instituir novas fontes destinadas a garantir a manutenção ou expansão da seguridade social (artigo 195, $\S 4^{\circ}$ ).

Além do conteúdo específico que lhes é inerente, as leis complementares à Constituição distinguem-se das demais pelo quorum exigido na sua aprovação - maioria absoluta, conforme o artigo 69 da Magna Carta - legitimando, dessa forma, a ascendência que exercem sobre as demais na estrutura hierarquizada dos atos normativos formadores do aludido Sistema.

Nesse contexto, a lei complementar à Constituição foi, durante muito tempo, e ainda é, por muitos doutrinadores, norma intermediária entre a Constituição e a lei ordinária. 
Alguns sustentam tal assertiva pelo escalonamento previsto no artigo 69 da Magna Carta, que prevê a instituição de leis complementares em seu inciso II, e a de leis ordinárias, em seu inciso III. Esse, contudo, não parece ser o melhor tratamento dado à matéria.

De fato, mister se faz discorrer sobre as características materiais e formais da lei, para se averiguar se ela se trata de lei ordinária ou complementar.

Para Michel Temer, jurista que defende a mesma posição hierárquica entre leis ordinárias e complementares, a grande diferença reside em seus aspectos material e formal, in verbis:

“(..)

Qual a diferença entre ela e lei ordinária?

A diferença reside em dois pontos bem claros.

O primeiro é o âmbito material de sua abrangência. Com efeito, em vários dispositivos o constituinte prescreve: "lei complementar disporá sobre isto ou aquilo'. 'A criação de Estado depende de lei complementar'. Poder-se-ia objetar: 'mas toda as demais matérias contidas na Constituição também dependem de lei e o legislador estabelece normas, preceitos, também sobre estas matérias'. É que, no tocante às lei complementares, em razão do disposto no art. 69 da $C F$, são aprováveis por maioria absoluta, o que se opõe à maioria simples.

Isto significa que a aprovacão de lei complementar demanda manifestacão de vontade mais qualificada do que a manifestação de vontade que se exige para aprovação de uma lei ordinária (26 votos têm uma expressão, 51 votos têm outra expressão, têm outro significado). E por que o constituinte estabeleceu esta distinção? É porque, na verdade, valorizou estas matérias. Deu-lhes maior relevo. Sendo essas matérias relevantíssimas (ao modo de ver do constituinte), estabeleceu fórmula que exige uma aprovação especial, manifestação mais significativa.

Portanto, a lei complementar se suporta nestes dois pontos: no âmbito material predeterminado pelo 
constituinte e no quorum especial para sua aprovação, que é diferente do quorum exigido para aprovação da lei ordinária.

A distinção entre a lei ordinária e a lei complementar reside no âmbito material expressamente previsto, que, por sua vez, é reforçado pela exigência de um quorum especial para a sua aprovação."4

Ora, em que pese a ilustre opinião de Michel Temer, nos inclinamos ao posicionamento da efetiva submissão hierárquica da lei ordinária à lei complementar.

Isso porque, utilizando-se das palavras no festejado jurista, ao exigir um quorum especial para a aprovação de leis complementares, o constituinte, “(...) valorizou estas matérias. Deu-lhes maior relevo. Sendo essas matérias relevantíssimas (ao modo de ver do constituinte), estabeleceu fórmula que exige uma aprovação especial, manifestação mais significativa".

Cumpre, portanto, trazer à baila o entendimento esposado pela nossa doutrina constitucionalista, conforme as lições de Alexandre de Moraes e Manoel Gonçalves Ferreira Filho, in verbis:

\footnotetext{
"Discussão eternizada na doutrina a eventual existência ou não de hierarquia entre lei complementar e lei ordinária obteve de ambos os lados grandes juristas e brilhantes argumentações.
}

Neste ponto, porém, filiamo-nos ao argumento de Manoel Gonçalves Ferreira Filho, por considerá-lo imbatível, pedindo venia para transcrevê-lo na íntegra:

' $E$ de se sustentar, portanto, que a lei complementar é um tertium genus interposto, na hierarquia dos atos normativos, entre a lei ordinária (e os atos que têm a mesma força que esta - lei delegada e decreto-lei) e a Constituição (e suas Emendas). Não é só, porém, o argumento de autoridade que apóia essa tese; a própria lógica o faz.

\footnotetext{
${ }^{4}$ TEMER, Michel. Elementos de Direito Constitucional. $15^{\text {a }}$ ed. São Paulo: Malheiros, 1999. p. $147 / 148$
} 
A Lei Complementar só pode ser aprovada por maioria qualificada, a maioria absoluta, para que não seja, nunca, o fruto da vontade de uma minoria ocasionalmente em condiçós de fazer prevalecer sua voz. Essa maioria é assim um sinal certo de maior ponderação que o constituinte quis ver associada ao seu estabelecimento. Paralelamente, devese convir, não quis o constituinte deixar ao sabor de uma decisão ocasional a desconstituição daquilo para cujo estabelecimento exigiu ponderação especial. Aliás, é princípio geral de direito que, ordinariamente, um ato só possa ser desfeito por outro que tenha obedecido à mesma forma.'

Assim, continua:

'... a lei ordinária, o decreto-lei e a lei delegada estão sujeitas à Lei Complementar. Em conseqüência disso não prevalecem contra elas, sendo inválidas as normas que a contradisserem. '

Nestes casos, não há como admitir-se que uma lei ordinária, aprovada por maioria simples, possa revogar a disciplina da lei complementar, aprovada por maioria absoluta da Câmara dos Deputados e do Senado Federal." ${ }^{\text {5 }}$ (grifos nossos e itálicos do original)

No mesmo sentido, se posiciona Caio Mário da Silva Pereira:

“(...) Hierarquicamente, a lei complementar sobrepõe-se à ordinária, de tal forma que a lei ordinária não pode revogar a complementar, nem contrariar suas disposições. As leis complementares integram o processo legislativo (constituição de 1988, art. 59), aprovadas por maioria absoluta (art. 69)."

Por outro lado, se a COFINS foi concebida à luz do artigo 195, inciso I, da Lei das Leis, e, as contribuições admitidas nestes incisos podem ser instituídas por lei ordinária, por que razão mobilizou-se o Congresso Nacional a instituir aquele tributo mediante o processo legislativo aplicável

\footnotetext{
${ }^{5}$ MORAES, Alexandre de; FILHO, Manoel Gonçalves Ferreira. Direito Constitucional. $5^{\mathrm{a}}$ ed. São Paulo: Atlas. p. 501/502.

${ }^{6}$ PEREIRA, Caio Mário da Silva. Instituições de Direito Civil. Volume I. $18^{\mathrm{a}}$ ed. Rio de Janeiro: Forense, 1995. p. 63.
} 
às leis complementares, havendo a Lei Complementar n. ${ }^{\circ}$ 70/91 recebido tal designação?

A resposta a essa pergunta encontra-se na Exposição de Motivos n. ${ }^{\circ}$ 149/DF, de 03 de dezembro de 1991, enviada juntamente com o projeto daquela lei complementar, firmada pelo Ex.mo Sr. Ministro Antônio Rogério Magri, então titular da pasta do Trabalho e da Previdência Social, exteriorizando o receio de outros enfrentamentos judiciais contra a nova exação diante da dificuldade de ampliação da cobertura previdenciária agravada com "sucessivas decisões judiciais, considerando inconstitucional a cobrança do chamado FINSOCIAL, sob o argumento de que, conceituado como tributo, deveria ser ele objeto de Lei Complementar, exigência jurídico-formal, que também se faz para a instituição das contribuições previstas no parágrafo $4^{\circ}$ do artigo 195 da Constituição, o que se atende com o projeto submetido à consideração de Vossa Excelência”.

Vale dizer, a instituição da COFINS revestiu a forma de lei complementar por medida de cautela face ao receio do Poder Executivo de vê-la identificada, pelo Poder Judiciário, como nova fonte de custeio da seguridade social, nos moldes facultados pelo artigo 194, § $4^{\mathrm{o}}$, da Constituição Federal, do que resultaria mais um fracasso a se associar aos tantos que já se fazia antever a época, alguns dos quais posteriormente confirmados quando do equacionamento definitivo das demandas pelo Supremo Tribunal Federal.

Nesse contexto, são pertinentes as palavras de Caio de Azevedo Trindade:

"Ora, sabido que lei complementar demanda maioria absoluta de Casa Legislativa para sua aprovação, enquanto que lei ordinária exige apenas maioria relativa. Se o Poder Legislativo entendeu por conceder isenção tributária através de lei complementar, está mais que óbvio que sua intenção foi exatamente "proteger" o favor fiscal de uma 
revogação por lei ordinária. Hoje, vê-se que a preocupação do legislador era pertinente.

A hierarquia das leis deve ser observada por dois aspectos que se encontram umbilicalmente ligados:

i) uma norma hierarquicamente superior jamais pode ser revogada por norma hierarquicamente inferior, uma vez que

ii) o processo (legislativo) de elaboração de cada norma é diverso, sendo que a complexidade do processo reformador é diretamente proporcional à hierarquia da lei.

A norma de maior hierarquia pode revogar a de menor; a recíproca, porém, é ilegal."” (grifos nossos)

Divide também a mesma opinião, os renomados professores Hugo de Brito Machado e Geraldo Ataliba:

"Meditando sobre o tema, relendo as referidas lições da doutrina, e especialmente relendo os dispositivos da Constituição, modificamos nosso ponto de vista. $\mathrm{Na}$ verdade a lei complementar é espécie normativa superior à lei ordinária, independentemente da matéria que regula, e mesmo que disponha sobre matéria a ela não reservada pela Constituição, não poderá ser revogada por lei ordinária.

A Superioridade hierárquica da lei complementar tem sido afirmada, sem qualquer questionamento, por eminentes constitucionalistas. $\mathrm{O}$ problema na verdade não está nessa superioridade, de resto conhecida sem qualquer objeção razoável, mas na questão de saber se a própria caracterização da lei complementar, como espécie normativa autônoma, depende de matéria regulada. Em outras palavras, o que se pode razoavelmente questionar é se uma lei complementar, pelo fato de tratar de matéria a ela não reservada pela Constituição, tem natureza de lei ordinária.

Ressalte-se, em primeiro lugar, que a superioridade hierárquica das normas jurídicas em geral é conferida pelo elemento formal. Não pelo material, pelo conteúdo da norma.(...)

\section{(...)}

Quando a lei ordinária trata de matéria que não está compreendida no campo da denominada reserva legal, $e$

\footnotetext{
${ }^{7}$ TRINDADE, Caio de Azevedo. A Isenção da Cofins para as Sociedades Civis de Prestação de Serviços Profissionais, uma Questão Infraconstitucional. Revista Dialética de Direito Tributário. São Paulo, n. ${ }^{\circ} 101$, p. 54/55, fev. 2004.
} 
que por isto mesmo poderia ser tratada por um ato normativo inferior, não se desnatura por isto. Nem poderá ser alterada, ou revogada, a não ser por outra lei. A fixação de prazo para o recolhimento do tributo, por exemplo, foi considerada pela jurisprudência como matéria alheia ao campo da reserva legal. Entretanto, no caso do IPI, considerou a jurisprudência que existindo, como era o caso, dispositivo de lei estabelecendo tal prazo, não poderia este ser alterado por ato de hierarquia inferior.

A rigor, não há vigente na Constituição qualquer norma, ou princípios, que expressa ou implicitamente autorize a conclusão de que a lei complementar somente pode cuidar das matérias a esta reservadas pela Constituição. Existem é certo, dispositivos que tornam determinadas matérias privativas de lei complementar, o que é rigorosamente diversa. A existência de um campo de reserva de lei complementar, todavia, não quer dizer que não possa a lei complementar cuidar de outras matérias. Pode, sim, e deve, o legislador adotar a forma de lei complementar para cuidar não apenas das matérias a este entregues, em caráter privativo, pelo constituinte, mas também de outras, às quais deseja imprimir maior estabilidade, ao colocá-las fora do alcance de maiorias ocasionais, ou até dos denominados acordos de lideranças.

\section{(...)}

A doutrina segundo a qual a lei complementar, naquilo em que cuida de matérias a ela não reservadas pela Constituição, pode ser alterada por lei ordinária, amesquinha o princípio da segurança jurídica, na medida em que o campo das matérias atribuídas pela Constituição à lei complementar é impreciso. Abre ensejo a que muitas questões sejam suscitadas, por exemplo, a respeito do que se deve entender por normas gerais de direito tributário.

A vida e o espírito postulam um direito justo, mas pedem também, e antes de tudo, segurança, e portanto um direito certo, ainda que menos justo. 'A certeza do direito, sem a qual não pode haver uma regular previsibilidade das decisões dos tribunais, é na verdade condição evidente e indispensável para que cada um possa ajuizar das conseqüências de seus actos, saber quais os bens que a ordem jurídica the garante, traçar e executar os seus planos de futuro'.

Não se pode dizer que uma, ou a outra solução, realiza, ou deixa de realizar, o valor justiça. $\mathrm{O}$ valor segurança, todavia, é induvidosamente melhor preservado pela compreensão segundo a qual a superioridade hierárquica da lei 
complementar é sempre ditada pelo elemento formal que a distingue." (grifos nossos)

“(...) a Lei Complementar caracteriza-se pelo quorum de votação, e será, assim, lei complementar, ainda quando eventualmente cuide de matéria a ela não expressamente reservada pela Constituição". 9

"Abaixo das leis constitucionais, localizou as complementares, seguidas imediatamente pelas ordinárias. A hierarquia ideal corresponde a essa graduação.

A principal conseqüência jurídica reside na superioridade da lei complementar sobre a ordinária. E esta graduação tem, em muitos casos, conseqüências também de caráter formal como se verá.

Consiste a superioridade formal da lei complementar - como em geral das normas jurídicas eminentes, em relação às que lhe são inferiores - na impossibilidade jurídica de a lei ordinária alterá-la ou revogá-la. Nula é, pois, a parte desta que contravenha disposição daquela."

Em outras palavras, a lei que discipline matéria diversa da direcionada pela Lei Maior para ser regulada por lei complementar, ainda que publicada com essa denominação, numerada como lei complementar e aprovada pela unanimidade dos membros do Congresso Nacional, deve ser reconhecida como tal, e gozar de precedência conferida à lei complementar no universo do Direito.

Isto é o que nos ensina Ives Gandra da Silva Martins e José Ruben Marone, ao analisar a matéria objeto do presente estudo:

"No caso, a LC 70/1991 instituiu uma nova exação, no sistema tributário pátrio, incidente sobre o faturamento mensal, em substituição ao antigo Finsocial, com o escopo

\footnotetext{
${ }^{8}$ MACHADO, Hugo de Brito. Posição Hierárquica da Lei Complementar. Revista Dialética de Direito Tributário. São Paulo, n. ${ }^{\circ}$ 14, p. 20/22, nov. 1996.

${ }^{9}$ MACHADO, Hugo de Brito. Aspectos Fundamentais do ICMS. São Paulo: Dialética. p. 13/14.

${ }^{10}$ ATALIBA, Geraldo. Lei Complementar na Constituição. São Paulo: RT, 1971. p. 29.
} 
de financiar a seguridade social, com base no art. 195, I, da Constituição de 1988.

A partir dessa evidência, a liturgia da forma há de ser respeitada.

Conforme aduzido, a aludida LC 70, de 30.12.1991, instituidora da contribuição social sobre o faturamento Cofins, em seu retro art. $6^{\circ}$, II, isentou as sociedades civis de prestação de serviços profissionais relativos ao exercício de profissão regulamentada, registradas no Registro civil das Pessoas Jurídicas e constituídas exclusivamente por pessoas físicas domiciliadas no País, com base no ar. 175 do CTN.

Ratifique-se que, na isenção, o fato descrito hipoteticamente pelo legislador é praticado pelo sujeito passivo da relação tributária, dando ensejo ao nascimento da obrigação tributária, sendo que o crédito decorrente dele é excluído, em virtude da norma isencional, dispensando, assim, o contribuinte do pagamento.

A Lei Ordinária 7.430/1996, em seu artigo 56, ao determinar a contribuição das sociedades civis de prestação de serviços de profissão legalmente regulamentada para a seguridade social com base na receita bruta, observadas as normas da LC 70/1991, pretendeu revogar isenção concedida em sede de lei complementar, afrontando a hierarquia anteriormente delineada.

Ora, se lei complementar - cujas características de aprovação e competência supra-expostas têm maior relevância constitucional - determinou a exclusão do crédito tributário, por óbvio, tal determinação é intocável por lei ordinária, sujeita à aprovação sob critérios menos rígidos. Admitir a possibilidade de tal revogação seria ignorar a liturgia das formas e todas as determinações constitucionais, doutrinárias e jurisprudenciais que conceitualizam a hierarquia da lei complementar, abalando toda a estabilidade do direito positivo pátrio, com base em pretensa prerrogativa de legislador ordinário em ignorar comandos constitucionais e legais que balizam sua atividade legiferante.

Nesse contexto de privilégio jurídico do necessário princípio da hierarquia das leis para a própria proteção da Lei Maior, é certo que apenas lei complementar poderá revogar isenção contida na LC 70/1991 e nunca um ato administrativo normativo ou lei ordinária, pois, caso contrário, estar-se-ia possibilitando que a Constituição Federal seja alterada por atos infraconstitucionais." 11

${ }^{11}$ MARTINS, Ives Gandra da Silva; MARONE, José Ruben. Da isenção da Cofins contida no art. $6^{\circ}$, II, da LC 70, de 03.12.1991, e do direito de recuperação judicial por via da compensação dos valores indevidamente recolhidos a esse título. Revista Tributária e de Finanças Públicas. São Paulo, n. ${ }^{\circ}$ 55, p. 266/267, mar./abr. 2004. 
De fato, dispor de forma diversa é atentar para o princípio da segurança jurídica, conforme sustentado pelo ilustre Ministro Luiz Fux à época da revisão do disposto na Súmula n. ${ }^{\circ}$ 276/STJ, em seu voto-vogal, nos autos do AgRg em REsp n. ${ }^{\circ}$ 382.736/SC, in verbis:

"O EXMO. SR. MINISTRO LUIZ FUX: O Sr. Ministro José Delgado, com muita felicidade, tem destacado essa nova feição do Direito Tributário, que trata dos direitos fundamentais do contribuinte, estatuto do contribuinte, surpresa fiscal, enfim aquela confianca fiscal que o contribuinte deve ter em relacão ao Fisco, porque hoje já desmistificamos a idéia de que o interesse público é o interesse fazendário.

O interesse público é o interesse de cada um de nós. O conjunto dos interesses de todos nós perfaz o interesse público. Às vezes, o interesse da Fazenda é contra o interesse público e contra o interesse de todos nós.

Estamos no campo de uma lei complementar, votada para criar um benefício fiscal em prol do contribuinte com um quorum qualificado constitucionalmente. De sorte que o contribuinte tem o direito fundamental de ver excluído esse benefício fiscal por esse mesmo quorum que o instituiu. Esse princípio, hoje consagrado por toda a doutrina tanto pelas lições mais antigas de Rubens Gomes de Souza e Rui Barbosa Nogueira quanto pelos mais modernos como Roque Carraza e Hugo de Brito Machado, dentre tantos, esclarece mais ainda: além do direito inalienável do contribuinte de ver revogada uma isencão pelo mesmo quorum que a concedeu - na verdade, a revogação da isenção implica a criação de um novo tributo para o contribuinte -, como V. Exa. muito bem destacou, e para que seja criado esse novo tributo com base de cálculo e definições de quem seja o contribuinte, efetivamente é necessária uma lei complementar.

Em nome da seguranca jurídica, mantenho a nossa Súmula com esses fundamentos, e, pedindo vênia aos Colegas que pensam em sentido contrário e, notadamente, ao Sr. Ministro Humberto Gomes de Barros, que pediu vista dos autos, para acompanhar a divergência inaugurada pelo Sr. Ministro Francisco Peçanha Martins.

Nego provimento ao agravo regimental.” (grifos nossos)

Dessa forma, podemos afirmar com segurança que a hierarquia da lei complementar perante a lei ordinária decorre de sua maior 
complexidade formal prevista na Constituição Federal, e que, mesmo tratando de matéria diversa da Constituição, deverá ser tratada como tal. 


\section{CAPÍTULO III}

\section{Os Efeitos da Decisão Proferida nos Autos da Ação Declaratória de Constitucionalidade $n .^{\circ} 01$}

\section{O Objeto do Processo e os Limites Objetivos da Coisa Julgada.}

Para que se dê a adequada resposta aos reais efeitos da decisão proferida nos autos da Ação Declaratória de Constitucionalidade n. ${ }^{\circ}$ 01, cumpre inicialmente definir a coisa julgada e delinear os seus limites objetivos, em face do pedido formalizado nos autos da Ação Declaratória em questão e de sua causa de pedir.

De fato, havia um expressivo número de ações substancialmente idênticas - em curso no judiciário, amparadas na suposta inconstitucionalidade da Lei Complementar n. ${ }^{\circ}$ 70/91, nas quais os contribuintes alegavam que a COFINS:

a) resultava em bitributação, por incidir sobre a mesma base de cálculo do PIS;

b) feria o princípio da não cumulatividade dos impostos da União;

c) como contribuição social, não poderia ser arrecadada e fiscalizada pela Receita Federal;

d) tratava-se, a rigor, de imposto inominado, como já reconheceu o STF, fruto da competência residual da União; 
e) violava o princípio constitucional da anterioridade, uma vez que o D.O. de 31.01.91 só circulou no dia 02.01.92.

Nesse contexto, o Presidente da República, a Mesa do Senado Federal e a Mesa da Câmara dos Deputados, com fundamento no art. 103, § $4^{\mathrm{o}}$, da Constituição Federal, com a redação dada pela Emenda Constitucional n. ${ }^{\circ}$ 03, de 1993, ajuizaram ação declaratória de constitucionalidade $^{12}$ objetivando a declaração de constitucionalidade da "Lei Complementar n. ${ }^{\circ}$ 70, de 30 de dezembro de 1991, que instituiu contribuição para financiamento da Seguridade Social - em especial, os arts. $1^{\circ}, 2^{\circ}, 9^{\circ}, 10$ e 13 da referida lei" (RTJ 156, 722), com fundamento nos seguintes argumentos:

a) que a alegada ocorrência de bitributação entre a contribuição

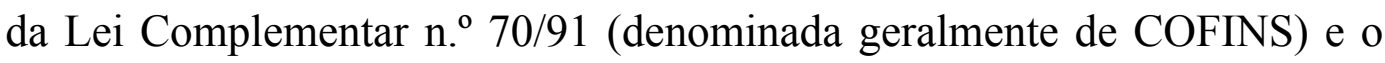
PIS, por incidirem ambas sobre o faturamento, não prospera porque, além de não se aplicar ao caso, a vedação do inciso I do artigo 154, pelo fato de a COFINS não ser imposto novo, tanto ela quanto a o PIS, têm sede constitucional (art. 195, I e art. 239)" (RTJ 156, 727), estando a existência de duas contribuições incidentes sobre a mesma base de cálculo autorizada pela Constituição Federal;

b) que o princípio da não cumulatividade não seria obstáculo à COFINS, eis que sua origem e fonte de validade situam-se no artigo 195, I e não no artigo 195, parágrafo, $\S 4^{\circ}$;

\footnotetext{
${ }^{12}$ Quanto ao cabimento da Ação Declaratória de Constitucionalidade, cumpre trazer à baila breves comentários de Zeno Veloso (in "Controle Jurisdicional de Constitucionalidade", $2^{\mathrm{a}}$ ed. Belo Horizonte: Del Rey, 2000, p. 285), in verbis:

“(...) Vigorando em nosso ordenamento o princípio da presunção da constitucionalidade das leis, a ação declaratória de constitucionalidade pressupões um estado de incerteza, o estabelecimento de uma controvérsia, comprometendo esta presunção, o que ocorre, por exemplo, quando a legitimidade de uma lei vem sendo apreciada em juízos de primeiro e segundos graus, com opiniões divergentes, soluções conflitantes, gerando apreensões e insegurança no meio social. A Corte Suprema é chamada e intervém para espancar a dúvida, dar a última palavra, com eficácia geral e efeito vinculante, resolvendo o problema, imprimindo certeza e quietude nas relações jurídicas que se baseiam na morna em questão.(...)"
} 
c) que a delegação da arrecadação e fiscalização, permitida pelo artigo $7^{\circ}$ do Código Tributário Nacional, não interfere na natureza jurídica da COFINS, pois o importante é que a própria Lei Complementar n. ${ }^{\circ} 70 / 91$ garante a sua destinação exclusiva às despesas com atividades-fins das áreas de saúde, previdência e assistência social;

d) que a transmutação da natureza da contribuição sobre o faturamento para o novo ordenamento constitucional - de imposto para contribuição social - tornou-se clara nos termos do voto do Ministro Moreira Alves, na ocasião em que relatou o RE n. ${ }^{\circ}$ 146.133-9; e

e) que não foi violado o princípio da anterioridade da lei, porque as contribuições sociais previstas no artigo 195 da $\mathrm{CF} / 88$ estão dele expressamente excepcionadas, pelo parágrafo $6^{\circ}$ do referido artigo, estando sujeitas somente ao prazo de noventa dias que deve existir entre a publicação da lei e a exigência da contribuição, fato este devidamente respeitado.

Assim, definido o pedido e a respectiva causa de pedir, cumpre destacar que, conforme o disposto do artigo 26 da Lei n. ${ }^{0}$ 9.868/99 ${ }^{13}$, "a decisão que declara a constitucionalidade ou inconstitucionalidade em Ação Declaratória de Constitucionalidade é irrecorível, ressalvada a interposição de embargos de declaração, não podendo, também, ser objeto de ação rescisória".

No caso da Ação Declaratória de Constitucionalidade, a coisa julgada material ocorre logo após o proferimento da decisão do Supremo Tribunal Federal, uma vez que o comando que emerge da parte dispositiva do acórdão não está mais sujeita a recurso ordinário nem extraordinário,

13 A Lei n. ${ }^{\circ}$ 9.868/97 dispõe sobre o processo e julgamento da Ação Direta de Inconstitucionalidade e da Ação Declaratória de Constitucionalidade perante o Supremo Tribunal Federal. 
conforme expressamente definido no artigo 467 do Código de Processo Civil, in verbis:

\footnotetext{
“Art. 467. Denomina-se coisa julgada material a eficácia, que torna imutável e indiscutível a sentença, não mais sujeita a recurso ordinário ou extraordinário"
}

Há que se chamar a atenção também para os limites objetivos da coisa julgada, disposto no artigo 468 do Código de Processo Civil, que prescreve:

\section{"Art. 468. A sentença, que julgar total ou parcialmente a lide, tem força de lei nos limites da lide e das questões decididas."}

Ora, verifica-se, desde logo, que não foi objeto de pedido que a lei complementar fosse declarada ordinária. De fato, o relator da ação, Ministro Moreira Alves, afirma que "embora os autores requeiram, na inicial, a declaração de constitucionalidade da Lei Complementar n. ${ }^{\circ}$ 70, de 30 de dezembro de 1991, dizendo que os fazem em especial quanto aos seus artigos $1^{\circ}, 2^{\circ}, 9^{\circ}, 10$ e 13 , o certo é que somente eles são transcritos e apenas a eles, no tocante à contribuição social por ela instituída, diz respeito a fundamentação do pedido, o que demonstra que, em verdade, o objeto da presente ação fixado pelos autores na inicial se restringe a esses dispositivos legais e não a toda Lei Complementar n. $70 / 91$ que, inclusive, contém normas estranhas à contribuição social em causa (assim, por exemplo, os artigos 11, 12 e 14)" (RTJ 156, 741).

Essa, inclusive, é a razão pela qual o acórdão da Ação Declaratória de Constitucionalidade . $^{\circ} 01$ sequer fez referência ao artigo $6^{\circ}$, inciso II, da Lei Complementar n. ${ }^{\circ}$ 70/91, sobre o qual figura a controvérsia concernente à tributação pela COFINS das receitas das sociedades de profissionais, conforme se verifica através da leitura de sua ementa, in verbis: 
"Ação Declaratória de Constitucionalidade. Artigos $1^{\circ}, 2^{\circ}, 9^{\circ}$ (em parte), 10 e 13 (em parte) da Lei Complementar n. ${ }^{\circ} 70$, de 30/12/91. COFINS.

A delimitação do objeto da ação declaratória de constitucionalidade não se adstringe aos limites do objeto fixado pelo autor, mas estes estão sujeitos aos lindes da controvérsia judicial que o autor tem que demonstrar.

Improcedência das alegações de inconstitucionalidade da contribuição social instituída pela Lei Complementar n. ${ }^{\circ}$ 70/91 (Cofins).

Ação que se conhece em parte, e nela se julga procedente, para declarar-se, com os efeitos previstos no parágrafo $2^{\circ}$ do artigo 102 da Constituição Federal, na redação da Emenda Constitucional . $^{\circ}$ 03, de 1993, a constitucionalidade dos artigos $1^{\circ}, 2^{\circ}$ e 10 , bem como das expressões 'A contribuição social sobre o faturamento de que trata esta lei não extingue as atuais fontes de custeio da Seguridade Social' contidas no artigo $9^{\circ}$, e das expressões 'Esta lei complementar entra em vigor na data de sua publicação, produzindo efeitos a partir do primeiro dia do mês seguinte nos noventa dias posteriores, àquela publicação,...' constantes do artigo 13, todos da Lei Complementar n. ${ }^{\circ} 70$, de 30 de dezembro de 1991.”

\section{A Afirmação de que a Lei Complementar $n .^{\circ} 70 / 91$ é Materialmente Ordinária Não Possui Efeito Vinculante.}

Não se pode olvidar o fato de que o STF afirmou ser a Lei Complementar n. ${ }^{\circ}$ 70/91 materialmente lei ordinária. Contudo, tal assertiva constitui apenas um obter dictum $^{14}$, simples declaração incidental ocorrida à época do julgamento realizado pelo Plenário daquela Corte.

Nesse contexto, o efeito vinculante restringe-se tão-somente aos dispositivos da Lei Complementar n. ${ }^{\circ}$ 70/91 que foram invocados pelos autores, cabendo afirmar, com segurança, que a Corte Máxima de Justiça ainda não apreciou o mérito da matéria objeto do presente estudo.

Esta questão, inclusive, já foi analisada pelo STF, que entendeu que $o$ obter dictum em questão não possui efeito vinculante, não fazendo, portanto, coisa julgada:

\footnotetext{
${ }^{14}$ Letra morta, sem finalidade.
} 
“(..)

É bem verdade que, no caso, o voto do Ministro Moreira Alves sagrou-se vencedor. Todavia, é certo que o efeito vinculante das decisões em Ações Declaratórias de Constitucionalidade não abrange os chamados obter dicta, proferidos em votos específicos.

No caso da ADC 1, a afirmação do Ministro Moreira Alves de que a Lei Complementar 70/91 possui natureza de lei ordinária é um típico obter dicutm. Isso porque, da análise do acórdão da ADC 1, não se percebe a afirmação citada como fundamento determinante da decisão - não alcancando, assim, 0 efeito vinculante.

De fato, tudo leva a crer que o afirmado pelo Ministro Moreira Alves constitui-se um verdadeiro obter dictum. Tanto que o Ministro Carlos Velloso foi expresso em despacho na Rcl 2475:

'O efeito vinculante é da decisão proferida na ação declaratória de constitucionalidade. A decisão proferida na ADC 1/DF, relatada pelo Ministro Moreira Alves, limitou-se a 'conhecer em parte da ação, e, nessa parte, julgá-la procedente, para declarar, com os efeitos vinculantes previstos no parágrafo $2^{\circ}$ do artigo 102 da Constituição Federal, na redação da Emenda Constitucional $\mathrm{n}^{\mathrm{o}} 3 / 93$, a constitucionalidade dos artigos $1^{\circ}, 2^{\circ}$ e 10', bem como da expressão 'A contribuição social sobre o faturamento de que trata esta lei complementar não extingue as atuais fontes de custeio da Seguridade Social', contida no artigo $9^{\circ}$, e também da expressão 'Esta lei complementar entra em vigor na data de sua publicação, produzindo efeitos a partir do primeiro dia do mês seguinte aos noventa dias posteriores, àquela publicação,... ', constante do artigo 13, todos da Lei Complementar $\mathrm{n}^{\circ}$ 70, de 30.12.1991" (RTJ 156/722). $\underline{\mathbf{A}}$ decisão, está-se a ver, não assentou ser a Lei Complementar 70/91 lei complementar simplesmente formal. É verdade que, no voto do Ministro Relator isso foi dito (RTJ 156/745). Trata-se, entretanto, de um obiter dictum. Também no meu voto expressei obiter dictum igual (RTJ 156/752). Assim, pelo menos ao primeiro exame, não vejo configurado o fumus boni juris que autorizaria o deferimento da liminar'.

Outro motivo impede o seguimento da presente Reclamação.

Se é verdade que lei ordinária alterou o disposto na lei complementar no que tange à isenção da COFINS, também é verdade que decisão deste Tribunal na ADC 1 não julgou a alteração da lei complementar, mas a sua constitucionalidade antes da alteração. Ou seja, ainda que o afirmado pelo Ministro Moreira Alves representasse a voz da maioria - e não um obiter dictum -, a violação à autoridade do 
julgamento desta Corte seria, quando muito, indireta, pois não foi objeto de julgamento pelo Tribunal a alteração da lei complementar por lei ordinária posterior e nem se disse que isso deveria ter sido feito.

Diante do exposto, e com base no art. $21, \S 1^{\circ}$ do RISTF, nego seguimento à Reclamação." (grifos nossos)

(Rcl. n. ${ }^{\circ}$ 2.517/RJ, $2^{\text {a }}$ Turma, Rel. Min. Joaquim Barbosa, j. 18 dez. 2003)

Ora, outro não poderia ser o entendimento de nossos tribunais, uma vez que o artigo 469 do Código de Processo Civil, em seu inciso I, estipula:

“Art. 469. Não fazem coisa julgada:

I - os motivos, ainda que importantes para determinar o alcance da parte dispositiva da sentença;

(...)" (grifos nossos)

Ou seja, não abrange a res iudicata os fundamentos que não integram a parte dispositiva da decisão, sendo, portanto, impertinente a afirmativa da Fazenda Nacional de que este obter dictum possui força vinculante, fazendo, portanto, coisa julgada.

Nesse sentido, faz-se oportuno invocar a doutrina mais acatada na matéria, exemplificada nos seguintes pronunciamentos:

\footnotetext{
"No sistema do Código (artigos 468 e 469), só o pronunciamento judicial sobre o pedido é idôneo para adquirir a autoridade da coisa julgada. Esta não abrange a fundamentacão da sentença (exemplos: a dívida principal, quando se cobram juros; a servidão, quando se pleitea indenização por suposto descumprimento o ônus; a relação contratual básica, quando se pede a condenação na multa convencional por inadimplemento da obrigação)." ${ }^{.15}$ (grifos nossos)
}

\footnotetext{
${ }^{15}$ MOREIRA, José Carlos Barbosa. Novo Processo Civil Brasileiro. 22 $2^{\mathrm{a}}$ edição, Rio de Janeiro, Forense, 2002. p. 92.
} 
"Os motivos, ainda que importantes para determinar o alcance do que decide a sentença ('parte dispositiva da sentença'), não fazem coisa julgada material. No processo não mais se podem discutir e julgar porque o processo se extinguiu. Fora do processo, o que pode ter eficácia de coisa julgada (material) é o enunciado sentencial. O que se pode acontecer e por vezes acontece é que se têm de apreciar para se saber qual o verdadeiro alcance de decisão ou das decisões. Porém, mesmo em tais circunstâncias, não fazem coisa julgada, nem têm eficácia de coisa julgada material (art. 469, I, verbis 'ainda que importantes para determinar o alcance da patê dispositiva da sentença'). Estáse apenas no plano da interpretação dos enunciados da sentença, em pesquisa lógica. Fez bem o art. 469, I, em repelir o que alguns juristas queriam conferir aos motivos."16 (grifos nossos)

Quanto aos limites objetivos da coisa julgada e os efeitos objetivos da decisão proferida em Ação Declaratória de Constitucionalidade, pedimos especial atenção aos ensinamentos de Luís Roberto Barroso:

"O limite objetivo da coisa julgada segue a regra geral, cingindo-se à matéria discutida, tal como enunciada na parte dispositiva da decisão. O conteúdo do dispositivo em uma ação declaratória de constitucionalidade que venha a acolhida terá teor análogo ao seguinte: 'O Tribunal, por maioria (por unanimidade), julga procedente a ação declaratória, para declarar a constitucionalidade dos arts. $x \mathrm{e}$ $y$ da Lei n. ${ }^{\circ} \mathrm{W} / 00$ '.

Por força da eficácia preclusiva da coisa julgada, uma vez decidida a ação declaratória, já não será mais possível obter novo pronunciamento judicial acerca da mesma matéria. De fato, se o pedido tiver sido julgado improcedente, isso significará que a norma objeto de apreciação era inconstitucional, hipótese em que terá deixado de integrar validamente o sistema jurídico, não sendo possível ressuscitá-la. E, se o pedido tiver sido julgado procedente, não haveria sequer interesse em nova manifestação judicial, ainda que fosse cabível. Já a eficácia vinculativa impede que juízes e tribunais, ao julgar os casos que lhe são submetidos, deixem de observar, como premissa lógica e necessária, a constitucionalidade ou inconstitucionalidade estabelecida no julgado do Supremo Tribunal Federal."

\footnotetext{
${ }^{16}$ MIRANDA, Pontes de. Comentários ao Código de Processo Civil. Tomo V. $3^{\mathrm{a}}$ ed. Rio de Janeiro: Forense, 1997. p. 137.

${ }^{17}$ BARROSO, Luís Roberto. O Controle de Constitucionalidade no Direito Brasileiro: Exposição sistemática da doutrina e análise crítica da jurisprudência. São Paulo: Saraiva, 2004. p. 185/186.
} 
Frise-se que o referido autor, em nota de rodapé da mesma obra, faz expressa referência ao dispositivo da Ação Declaratória de Constitucionalidade n. $^{\circ} 01$ como exemplo de parte conclusiva de algumas Ações Declaratórias de Constitucionalidade julgadas procedentes.

O Supremo Tribunal Federal também já se pronunciou nesse mesmo sentido, sendo oportuno trazer à baila o teor dos seguintes arestos:

"EMENTA: Recurso: sucumbência inexistente: falta de interesse processual em recorrer para questionar simples obiter dicta da decisão recorrida, cujo dispositivo julgou extinta sem julgamento do mérito a ação proposta contra a recorrente. Se sequer fazem coisa julgada os motivos da decisão (C.Pr.Civ., art. 469, I) - ao contrário do que dispunha o Código antigo, com relação às "premissas necessárias" dela -, a fortiori, nenhum efeito fora do processo poderiam ter simples obiter dicta contidos no acórdão malgrado em sentido adverso ao dispositivo, fundado em outra circunstância, prejudicial.” (grifos nossos) (AI 222.267/PR; Primeira Turma; Rel. min. Sepúlveda Pertence; j. 14 dez. 1998)

"COMPETÊNCIA - DEMANDA RESCISÓRIA. A competência e fixada tendo em conta a origem da decisão rescindenda. Sendo esta de Órgão do Supremo Tribunal Federal, a ele cumpre processar e julgar a demanda rescisória. INICIAL - INEPCIA - POSSIBILIDADE JURÍDICA DO PEDIDO. Descabe confundir a condição da ação com a procedência do pedido formulado. Aprecia-se a primeira a partir do que contemplado na ordem jurídica e estando a rescisória calcada na alegação de mau trato a literal disposição de lei e a coisa julgada, impossível e concluir pela carência. COISA JULGADA CARACTERIZAÇÃO - FUNDAMENTOS CONTIDOS NO TÍTULO JUDICIAL. A teor do artigo 469 do Código de Processo Civil, os motivos e a verdade dos fatos estabelecidos como fundamento da sentença não fazem coisa julgada, o mesmo ocorrendo quanto ao exame de questão prejudicial decidida incidentemente no processo, exceção aberta se a hipótese tem enquadramento no artigo 470 do referido Diploma. A coisa julgada pressupõe, ainda, a tríplice identidade - de pessoas, de causa de pedir e pedido. Não há falar no fenômeno quando diversas as demandas reveladoras dos títulos em cotejo, quer em relação as partes, quer no tocante as causas de pedir e aos pedidos." (grifos 
nossos) (AR 1343/SC; Tribunal Pleno; Rel. Min. Marco Aurélio; j. 18 fev. 1993)

"Não fazem coisa julgada os motivos, ainda que importantes para determinar o alcance da parte dispositiva da sentença. $O$ juiz, enquanto razoa, não representa o Estado; representa-o, enquanto lhe afirma a vontade. As razões de decidir preparam, em operação lógica, a conclusão a que vai chegar o juiz no ato de declarar a vontade da lei (grifos nossos) (ED no RE 94.530/BA; Primeira Turma; Rel. Min. Alfredo Buzaid; j. 21 mai. 1982)

\section{"EMENTA: - MANDADO DE SEGURANÇA - CONCURSO - LITISCONSÓRCIO.}

1 - Tratando-se de litisconsórcio facultativo, não é nula a decisão proferida em processo sem o chamamento a lide do pretenso litisconsorte, principalmente no caso "sub judice", em que o único interesse legítimo do recorrente seria o de candidatar-se a novo concurso, caso o atual fosse declarado nulo, direito este assegurado a qualquer cidadão.

2 - Em mandado de segurança, onde se discute direito liquido e certo, a interposição, pelo recorrente, do recurso extraordinário, teria sanado, de qualquer modo, a invocada irregularidade, pois a sua não participação nos atos anteriores do processo nenhum prejuízo poderia the acarretar.

3 - A decisão recorrida não ofendeu a coisa julgada, já que não a integram os motivos; a única parte do acórdão proferido no mandado de segurança anterior que transitou em julgado foi a expositiva, que atribuiu ao autor o bem pretendido (art. $469 \mathrm{do} \mathrm{cpc} / 73$ ).

4 - A decisão do conselho de justiça que homologa ou não o concurso esta sujeita, por ser tipicamente administrativa, ao crivo do tribunal, quando provocado por qualquer interessado. recurso extraordinário não conhecido." (grifos nossos) (RE 84.664/DF; Primeira Tuma; Rel. min. Cunha Peixoto; j. 04 mai. 1976)

Ora, em que pesem as notáveis decisões em questão, nos posicionamos no sentido de que a questão em torno da coisa julgada comporta análise de natureza infraconstitucional, podendo acarretar, no máximo, violação reflexa à Constituição Federal. 
Destarte, como bem se sabe, tem-se violação reflexa à Constituição quando o seu reconhecimento depende de rever a interpretação dada à norma ordinária pela decisão recorrida. Admitir eventual recurso por ofensa reflexa à Constituição seria transformar em questões constitucionais todas as controvérsias sobre a interpretação da lei ordinária e misturar as competências repartidas entre o Supremo Tribunal Federal e os Tribunais Superiores, razão pela qual é terminantemente vedada pela nossa Corte Constitucional.

Nesse sentido, transcrevemos recentes decisões proferidas pela Egrégia Corte Constitucional, in verbis:

"E M E N T A: AGRAVO DE INSTRUMENTO ALEGADA VIOLAÇÃO AOS PRECEITOS INSCRITOS NO ART. 5, II, XXXV, XXXVI E LV, NO ART. 93, IX, E NO ART. 105, III, TODOS DA CONSTITUIÇÃO DA REPÚBLICA - AUSÊNCIA DE OFENSA DIRETA À CONSTITUIÇÃO - CONTENCIOSO DE MERA LEGALIDADE - RECURSO IMPROVIDO.

- As alegações de desrespeito aos postulados da legalidade, da inafastabilidade do controle jurisdicional, da coisa julgada, da motivação dos atos decisórios e da plenitude de defesa, por dependerem de exame prévio e necessário da legislação comum, podem configurar, quando muito, situacões caracterizadoras de ofensa meramente reflexa ao texto da Constituição, o que não basta, só por si, para viabilizar 0 acesso à via recursal extraordinária. Precedentes.

- A discussão em torno da integridade da coisa julgada, por reclamar análise prévia e necessária dos requisitos legais, que, em nosso sistema jurídico, conformam o fenômeno processual da "res judicata", torna incabível o recurso extraordinário. É que, em tal hipótese, a indagação em torno do que dispõe o art. $5^{\circ}$, XXXVI, da Constituição - por supor o exame, "in concreto", dos limites subjetivos (CPC, art. 472) e/ou objetivos (CPC, arts. 468, 469, 470 e 474) da coisa julgada - traduz matéria revestida de índole infraconstitucional, podendo caracterizar situação de eventual conflito indireto com o texto da Carta Política (RTJ 182/746), circunstância que pré-exclui a possibilidade de adequada utilização do recurso extraordinário. Precedentes.

- A jurisprudência do Supremo Tribunal Federal firmou entendimento no sentido de que o exame dos requisitos de admissibilidade do recurso especial, dirigido ao Superior Tribunal de Justiça, não viabiliza o acesso à via recursal 
extraordinária, por tratar-se de tema de caráter eminentemente infraconstitucional, exceto se o julgamento emanado dessa Alta Corte judiciária apoiar-se em premissas que conflitem, diretamente, com o que dispõe o art. 105, III, da Carta Política. Precedentes. Situação inocorrente no caso." (grifos nossos) (AgR no AI 452.174/GO; Segunda Turma; Rel. min. Celso de Mello; j. 09 set. 2003)

"Coisa julgada. Prequestionamento de questão constitucional. Não há prequestionamento implícito, ainda quando se trate de questão constitucional. Ademais, o conceito de coisa julgada, e, portanto, a fixação de seus limites (no caso, discutiu-se o alcance do inciso I do art. 469 do C.P.C.), e matéria de ordem legal, e não constitucional. Agravo regimental a que se nega provimento." (grifos nossos) (AgR no AI 75.355/MG; Segunda Tuma; Rel. min. Moreira Alves; j. 30 mar. 1979)

"EMENTA: Trabalhista. Competência. Conflitos intersindicais relativos à representação da categoria. Apreciação da matéria conforme art. 469, do CPC. Ofensa indireta à CF. Recurso não provido." (grifos nossos) (AgR no AI 174.477; Segunda Turma; rel. min. Nelson Jobim; j. 06 out. 1998)

Dessa forma, não sendo postulado nos autos da Ação Declaratória de Constitucionalidade $n .{ }^{\circ} 01$ que fosse declarada ser a Lei Complementar n. ${ }^{\circ}$ 70/91 materialmente ordinária, podemos concluir que a afirmação do Ministro Moreira Alves constitui mero obter dictum, que não possui efeito vinculante.

Outrossim, ainda que assim não fosse, o instituto da coisa julgada comporta análise de natureza infraconstitucional, acarretando, no máximo violação reflexa à Constituição Federal, que por sua vez, não confere competência ao STF para julgamento da matéria. 


\section{CAPÍTULO IV}

\section{A Competência Para Julgamento de Conflitos Entre Lei Complementar e Lei Ordinária}

Por fim, se não bastassem os argumentos aduzidos no capítulo anterior, que demonstram a completa ausência de competência do Supremo Tribunal Federal para julgamento de eventuais recursos sobre a matéria objeto do presente estudo, cumpre esclarecer que o tribunal competente para resolver eventual conflito entre lei ordinária e lei complementar é o Superior Tribunal de Justiça, face ao caráter infraconstitucional da controvérsia.

Como é sabido, os campos de competência do STF e do STJ, no julgamento de recurso extraordinário e especial, respectivamente, são definidos pela Carta Magna em seus artigos 102 , inciso III $^{18}$ e 105 , inciso III $^{19}$.

Em que pese parecer simples a distinção do campo de atuação de cada tribunal - ao STJ cabe a análise de matéria infraconstitucional e, ao

18 “Art. 102. Compete ao Supremo Tribunal Federal, precipuamente, a guarda da Constituição, cabendo-lhe:

(...)

III - julgar, mediante recurso extraordinário, as causas decididas em única ou última instância, quando a decisão recorrida:

a) contrariar dispositivo desta Constituição;

b) declarar a inconstitucionalidade de tratado ou lei federal;

c) julgar válida lei ou ato de governo local contestado em face desta Constituição.

d) julgar válida lei local contestada em face de lei federal."

19 “Art. 105. Compete ao Superior Tribunal de Justiça:

(...)

III - julgar, em recurso especial, as causas decididas, em única ou última instância, pelos Tribunais Regionais Federais ou pelos tribunais dos Estados, do Distrito Federal e Territórios, quando a decisão recorrida:

a) contrariar tratado ou lei federal, ou negar-lhes vigência;

b) julgar válido ato de governo local contestado em face de lei federal;

c) der a lei federal interpretação divergente da que lhe haja atribuído outro tribunal." 
STF, a análise de matéria constitucional - é comum termos ambas as cortes julgando as mesmas matérias, seja porque nossa Constituição Federal é demasiadamente analítica, seja porque algumas questões possuem sede legal e constitucional, seja porque umas das Cortes invadiu a esfera de competência da outra.

É exatamente o último caso que nos interessa nesse momento: a invasão de competência por parte de umas das Cortes Superiores.

Se a invasão se dá por parte do Superior Tribunal de Justiça, o problema pode ser perfeitamente resolvido, através do ajuizamento de Reclamação $^{20}$ pelo interessado, tendo o Supremo Tribunal Federal competência para reformar acórdão do Superior Tribunal de Justiça. Não obstante, se a invasão é perpetrada pela Corte Máxima, então nada se pode fazer, pois a ele cabe a última palavra no processo judicial. A questão, portanto, é bastante delicada. Se o Supremo Tribunal Federal usurpa competência do Superior Tribunal de Justiça, incide em inconstitucionalidade, e faz letra morta da Carta Política (art. 105, inciso III). Não obstante, tratar-se-á de inconstitucionalidade que jamais será decretada.

Além da observância do Texto Constitucional, há outro fundamento para justificar a preocupação com a correta distribuição de competência entre as Cortes Superiores. O Supremo Tribunal Federal não pode se tornar órgão revisor das decisões lavradas pelo Superior Tribunal de Justiça, sob pena deste não possuir razão de existir. A criação do Superior Tribunal de Justiça, com a Constituição de 1988, teve por

\footnotetext{
${ }^{20}$ Prevista no artigo 102, inciso I, alínea "l" da Constituição Federal, in verbis:

"Art. 102. Compete ao Supremo Tribunal Federal, precipuamente, a guarda da Constituição, cabendo-lhe:

I - processar e julgar, originalmente:

(...)

1) a reclamação para a preservação de sua competência originária, facultada a delegação de atribuições para a prática de atos processuais." (grifos nossos)
} 
fundamento, exatamente, desobstruir o Supremo Tribunal Federal, que passaria a apreciar, tão-somente, matéria de índole constitucional.

Passemos, então, à análise da questão que envolve o conflito entre leis complementares e leis ordinárias.

Ora, a Constituição Federal não dispõe sobre os institutos da revogação e da vigência de leis ordinárias e de leis complementares, razão pela qual, não há como vislumbrar ofensa à Carta Magna.

De fato, coube à Lei de Introdução ao Código Civil tratar sobre o tema, em seu artigo $2^{\circ}$, in verbis:

\footnotetext{
“Art. $2^{\circ}$ - Não se destinando à vigência temporária, a lei terá vigor até que outra a modifique ou revogue.

$\S 1^{\circ}$ - A lei posterior revoga a anterior quando expressamente o declare, quando seja com ela incompatível ou quando regule inteiramente a matéria de que tratava a lei anterior.

$\S 2^{\circ}$ - A lei nova, que estabeleça disposições gerais ou especiais a par das já existentes, não revoga nem modifica a lei anterior.

$\S 3^{\circ}$ - Salvo disposição em contrário, a lei revogada não se restaura por ter a lei revogadora perdido a vigência."
}

Certo é, que o artigo $2^{\circ}, \S 1^{\circ}$, da LICC fixa o princípio da 'lex posterior derogat priori". Contudo, deve-se levar em conta, in casu, a máxima "lex posterior inferiori non derogat priori superiori".

Nesse contexto, cumpre transcrever o entendimento adotado pela melhor doutrina, segundo os ensinamentos da festejada jurista Maria Helena Diniz, ao comentar a Lei de Introdução ao Código Civil, in verbis: 
ex., a Constituição prevalece sobre uma lei. Daí falar-se em inconstitucionalidade da lei ou de ilegitimidade de atos normativos diversos da lei, por contrariarem-na.

As normas só podem, portanto, ser revogadas por normas superiores ou eqüipolentes. A norma inferior não poderá afetar a superior; se a atingir, surgirá um conflito normativo, e a que vier a afetar a superior será antinômica (normwidrig), sendo imprescindível que tal antinomia aparente seja corrigida, uma vez que o conhecimento jurídico não tolerará contradição entre duas normas no mesmo sistema." ${ }^{21}$ (grifos nossos)

Ora, conforme analisado no capítulo II, não restam maiores dúvidas de que, ainda que a COFINS pudesse ter sido instituída por lei ordinária, isso não retira a natureza da lei que instituiu a isenção da COFINS para as sociedades profissionais - qual seja, complementar razão pela qual, deve ser aplicado o princípio em tela.

Neste sentido, trazemos à baila as seguintes ementas proferidas pelo Egrégio Superior Tribunal de Justiça, que demonstram a sua competência para julgamento da matéria em foco, in verbis:

"TRIBUTÁRIO E PROCESSUAL CIVIL. COFINS. ISENÇÃO. SOCIEDADE CIVIL DE ADVOGADOS. MENÇÃO REFLEXA E INDIRETA A PRINCÍPIOS CONSTITUCIONAIS. AUSÊNCIA DE FUNDAMENTOS EMBASADOS EM NORMAS CONSTITUCIONAIS. SÚMULA 276 DO STJ. INCIDÊNCIA.

1. Acórdão que assentou que lei ordinária (Lei $\mathrm{n}^{\circ}$ 9.430/96) pode revogar isenção tributária relativa ao recolhimento da COFINS concedida por lei complementar ( $\mathrm{LC} \mathrm{n}^{\circ} 70 / 91$ ), sem que haja violação a princípios constitucionais.

2. A matéria em questão, se lei ordinária pode revogar isenção tributária concedida por lei complementar, é solucionada toda no âmbito do contencioso infraconstitucional.

3. A mera menção, genérica e reflexa, no acórdão, de que nenhum princípio constitucional foi violado não demonstra que o julgado tenha se baseado em norma constitucional. Só há fundamento constitucional na decisão quando o acórdão analisa e interpreta, diretamente, determinada regra posta, explicitamente, na Lei Maior.

4. A $1^{\text {a }}$ Seção, conforme sabido, reafirmou sobre o assunto a existência, a validade e a eficácia da Súmula $\mathrm{n}^{\circ}$ 276: "As

\footnotetext{
${ }^{21}$ DINIZ, Maria Helena. Lei de Introdução ao Código Civil. São Paulo: Saraiva, 1994. p.69.
} 
sociedades civis de prestação de serviços profissionais são isentas de COFINS, irrelevante o regime tributário adotado." 5. Agravo regimental a que se dá provimento para, aplicando-se a Súmula 276 do STJ, dar provimento ao recurso especial fazendo com que seja reconhecida a isenção pretendida." (grifos nossos)

(AgRg no REsp n. ${ }^{\circ}$ 496.354/SC; Primeira Turma; Rel. Min. Teori Albino Zavaski; j. 02 dez. 2003)

"AGRAVO REGIMENTAL. TRIBUTÁRIO. COFINS. SOCIEDADE CIVIL. ESCRITÓRIO DE ADVOCACIA. ISENÇÃO. LC 70/91.

1. A isenção tributária concedida por Lei Complementar só pode ser revogada por lei de igual natureza e não por lei ordinária.

2. Agravo regimental improvido." (grifos nossos)

(AgRg no REsp n. ${ }^{\circ}$ 382.736/SC; Primeira Seção; Rel. Min. Castro Meira; j. 08 out. 2003)

Dessa forma, pelas simples leitura das ementas em epígrafe, verificamos que em nenhum momento os Ministros do Egrégio Superior Tribunal de Justiça suscitaram que o conflito entre lei ordinária e lei complementar é de competência do Supremo Tribunal Federal.

Transcrevemos, inclusive, o teor do voto-vista proferido pelo Ex.mo Ministro Humberto Gomes de Barros, nos autos do AgRg no REsp n. ${ }^{\circ} 382.736$, que reexaminou o disposto na Súmula n. ${ }^{\circ} 276$, e ressaltou a observância do princípio da segurança jurídica no presente caso, in verbis:

"MINISTRO HUMBERTO GOMES DE BARROS: O fundamento da pretensão revocatória da Súmula é o de que o Supremo Tribunal Federal teria declarado que a Lei Complementar $\mathrm{n}^{\circ}$ 70/91, embora formalmente complementar, substancialmente, seria lei ordinária, suscetível de revogação sem o quorum especial, necessário à criação de nova lei complementar. O tema é a âncora - como está na moda dizer daqueles que entendem que a nossa Súmula foi infeliz. Colaborei na formação da Súmula. Continuo, data vênia, convicto de que agimos acertadamente, ao sumular o tema.

Meditei sobre o tema, e consolidei minha certeza de que o tema é de nossa alcada. O próprio Supremo Tribunal Federal proclamou que o conflito entre lei ordinária e lei 


complementar trava-se no plano da

infraconstitucionalidade. Trago comigo o Agravo no

Recurso Extraordinário $n^{0}$ 274.362, no qual, o Supremo

Tribunal Federal, não conheceu recurso extraordinário envolvendo conflito entre normas de lei complementar e de lei ordinária. Então, a competência é nossa.

Meu entendimento assenta-se na ementa felicíssima do Recurso Especial $n^{\circ} 221.710 / R J$, em que o STJ indicou o rumo do Poder Judiciário brasileiro:

'A Lei Complementar $n^{\circ} 70 / 91$, em seu art. $6^{\circ}$, inc. II, isentou da COFINS, as sociedades civis de prestação de serviços de que trata o art. $1^{\circ}$ do Decreto-lei $\mathrm{n}^{\mathrm{o}} 2.397$, de 22 de dezembro de 1987, estabelecendo como condições somente aquelas decorrentes da natureza jurídica das referidas sociedades.

- A isenção concedida pela Lei Complementar n ${ }^{0}$ 70/91 não pode ser revogada pela Lei $n^{\circ} 9.430 / 96$, lei ordinária, em obediência ao princípio da hierarquia das leis.

- A opção pelo regime tributário instituído pela Lei no 8.541/92 não afeta a isenção concedida pelo art. $6^{\circ}$, II da L.C. 70/91. Entre os requisitos elencados como pressupostos ao gozo do benefício não está inserido o tipo de regime tributário adotado pela sociedade para recolhimento do Imposto de Renda.'

A orientação partiu da Segunda Turma. O acórdão foi lavrado pelo Sr. Ministro Francisco Peçanha Martins. Dele participaram o Ministro-Relator, a Ministra Eliana Calmon e os Ministros Franciulli Netto, Laurita Vaz e Paulo Medina. Para mim, essa é a orientação definitiva a ser seguida pelos tribunais e pelos contribuintes.

Outra razão, que adoto como fundamento de voto, finca-se na natureza do Superior Tribunal de Justiça. Quando digo que não podemos tomar lição, não podemos confessar que a tomamos. Quando chegamos ao Tribunal e assinamos o termo de posse, assumimos, sem nenhuma vaidade, o compromisso de que somos notáveis conhecedores do Direito, que temos notável saber jurídico. Saber jurídico não é conhecer livros escritos por outros. Saber jurídico a que se refere a CF é a sabedoria que a vida nos dá. A sabedoria gerada no estudo e na experiência nos tornou condutores da jurisprudência nacional.

Somos condutores e não podemos vacilar. Assim faz o STF.

\section{Nos últimos tempos, entretanto, temos demonstrado profunda e constante insegurança.}

Vejam a situação em que nos encontramos: se perguntarem a algum dos integrantes desta Seção, especializada em Direito Tributário, qual é o termo inicial para a prescrição da ação de repetição de indébito nos casos de empréstimo compulsório sobre aquisição de veículo ou combustível, cada um haverá de dizer que não sabe, apesar de já existirem dezenas, até centenas, de precedentes. Há dez anos que o Tribunal vem afirmando que 
o prazo é decenal (cinco mais cinco anos). Hoje, ninguém sabe mais.

Dizíamos, até pouco tempo, que cabia mandado de segurança para determinar que o TDA fosse corrigido. De repente, começamos a dizer o contrário. Dizíamos que éramos competentes para julgar a questão da anistia. Repentinamente, dizemos que já não somos competentes e que sentimos muito.

O Superior Tribunal de Justiça existe e foi criado para dizer o que é a lei infraconstitucional. Ele foi concebido como condutor dos tribunais e dos cidadãos. Em matéria tributária, como condutor daqueles que pagam, dos contribuintes.

Bem por isso, a Corte Especial proclamou que:

'PROCESSUAL - STJ - JURISPRUDÊNCIA NECESSIDADE DE QUE SEJA OBSERVADA.

O Superior Tribunal de Justiça foi concebido para um escopo especial: orientar a aplicação da lei federal e unificar-lhe a interpretação, em todo o Brasil. Se assim ocorre, é necessário que sua jurisprudência seja observada, para se manter firme e coerente. Assim sempre ocorreu em relação ao Supremo Tribunal Federal, de quem o STJ é sucessor, nesse mister. Em verdade, o Poder Judiciário mantém agrado compromisso com a justiça e a segurança. Se deixarmos que nossa jurisprudência varie ao sabor das convicções pessoais, estaremos prestando um desserviço a nossas instituições. Se nós - os integrantes da Corte - não observarmos as decisões que ajudamos a formar, estaremos dando sinal, para que os demais órgãos judiciários façam o mesmo. Estou certo de que, em acontecendo isso, perde sentido a existência de nossa Corte. Melhor será extingui-la.' (AEREsp 228432).

Dissemos sempre que sociedade de prestação de serviço não paga a contribuição. Essas sociedades, confiando na Súmula ${ }^{\circ}$ 276 do Superior Tribunal de Justiça, programaram-se para não pagar esse tributo. Crentes na súmula elas fizeram gastos maiores, e planejaram suas vidas de determinada forma. Fizeram seu projeto de viabilidade econômica com base nessa decisão. De repente, vem o STJ e diz o contrário: esqueçam o que eu disse; agora vão pagar com multa, correção monetária etc., porque nós, o Superior Tribunal de Justiça, tomamos a lição de um mestre e esse mestre nos disse que estávamos errados. Por isso, voltamos atrás.

Nós somos os condutores, e eu - Ministro de um Tribunal cujas decisões os próprios Ministros não respeitam - sinto-me, triste. Como contribuinte, que também sou, mergulho em insegurança, como um passageiro daquele vôo trágico em que o piloto que se perdeu no meio da noite em cima da Selva Amazônica: ele virava para a esquerda, dobrava para a direita e os passageiros sem nada saber, até que eles de repente descobriram que estavam perdidos: $O$ avião com o Superior Tribunal de Justiça está extremamente perdido. 
Agora estamos a rever uma Súmula que fixamos há menos de um trimestre. Agora dizemos que está errada, porque alguém nos deu uma lição dizendo que essa Súmula não devia ter sido feita assim.

Nas praias de Turismo, pelo mundo afora, existe um brinquedo em que uma enorme bóia, cheia de pessoas é arrastada por uma lancha. A função do piloto dessa lancha é fazer derrubar as pessoas montadas no dorso da bóia. Para tanto, a lancha desloca-se em linha reta e, de repente, descreve curvas de quase noventa graus. O jogo só termina, quando todos os passageiros da bóia estão dentro do mar. Pois bem, o STJ parece ter assumido o papel do piloto dessa lancha. Nosso papel tem sido derrubar os jurisdicionados.

Peço venia para acompanhar o Ministro Peçanha Martins. Com essas considerações e louvando-me nesse precedente da lavra do Sr. Ministro Francisco Peçanha Martins, peço vênia ao eminente Ministro-Relator para aderir à divergência". (grifos nossos)

Ora, carecem portanto de fundamento os inúmeros Recursos Extraordinários interpostos contra acórdãos proferidos pelo Superior Tribunal de Justiça, bem como as Reclamações ajuizadas perante o Supremo Tribunal Federal, sob a alegação de usurpação de competência do nosso Tribunal Constitucional.

Assim, como acima demonstrado, por não haver expressa previsão na Constituição Federal quanto aos institutos de revogação e vigência de leis, mas tão-somente na Lei de Introdução ao Código Civil, firma-se o entendimento de que o Supremo Tribunal Federal não possui competência para dirimir eventual conflito entre lei ordinária e lei complementar. 


\section{CONCLUSÃO}

$\mathrm{O}$ entendimento jurisprudencial relativo ao objeto do presente estudo é pacífico há anos perante o Superior Tribunal de Justiça, o que acarretou, inclusive, na edição de Súmula n. ${ }^{\circ} 276$, que demonstra de forma expressa o posicionamento daquela corte.

Mesmo revendo a Súmula em questão, decidiram os membros da Primeira Seção em manter a sua aplicação, em atenção ao princípio da segurança jurídica, e tendo em vista que isenção concedida por lei complementar, mesmo que materialmente ordinária, não pode ser revogada por lei ordinária.

De fato, é inadmissível pensar de forma diversa, seja porque a lei complementar exige quorum especial para sua aprovação, seja porque na Exposição de Motivos n. ${ }^{\circ}$ 149/DF, o Ex.mo Sr. Ministro Antônio Rogério Magri, então titular da pasta do Trabalho e da Previdência Social exteriorizou o seu anseio de ver aprovada a lei que instituiu a COFINS como lei complementar.

Outrossim, em que pese o posicionamento do Ex.mo Ministro Moreira Alves nos autos da Ação Declaratória de Constitucionalidade n. ${ }^{\circ}$ 01, cumpre salientar que a assertiva de que a Lei Complementar n. ${ }^{\circ}$ 70/91 é materialmente ordinária constitui apenas um simples incidente processual, incapaz de possuir efeitos vinculante e erga omnes. Com efeito, a matéria em questão sequer foi objeto do pedido da Ação Declaratória de Constitucionalidade.

Ora, ainda que assim não fosse, cumpre frisar que os efeitos da res iudicata e, portanto, a fixação dos seus limites, encontra-se disposta no Código de Processo Civil, norma infraconstitucional, cuja análise encontra- 
se sob a competência do Superior Tribunal de Justiça. Levar ao conhecimento do Supremo Tribunal Federal matéria relativa aos efeitos do trânsito em julgado da decisão proferida na Ação Declaratória de Constitucionalidade $n .^{\circ} 01$ é caracterizar a situação de conflito indireto com o texto da Carta Política, situação vedada de forma pacífica pela nossa Corte Constitucional.

Por fim, não obstante essas razões, eventual conflito entre lei ordinária e lei complementar deve ser dirimido pelo Superior Tribunal de Justiça, uma vez que é a Lei de Introdução ao Código Civil que dispõe sobre os institutos da revogação e da vigência de leis, não constando na Constituição Federal nenhum dispositivo sobre a matéria.

Dessa forma, a isenção da Cofins concedida pela Lei

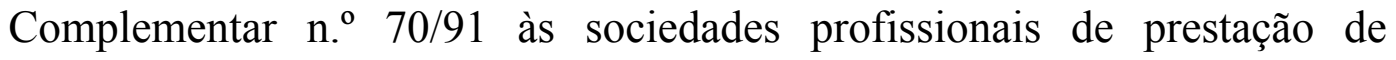
serviços relativos à profissão legalmente regulamentada está em pleno vigor, uma vez que é entendimento pacífico do Superior Tribunal de Justiça que tais sociedades ainda gozam desse benefício, com fulcro no princípio da hierarquia das normas. 


\section{BIBLIOGRAFIA}

BAETA, Zínia. Supremo suspende isenção da Cofins. Valor Econômico, São Paulo, , 7 jun. 2004.

BARROSO, Luís Roberto. O Controle de Constitucionalidade no Direito Brasileiro: Exposição sistemática da doutrina e análise crítica da jurisprudência. São Paulo: Saraiva, 2004. p. 299.

CARRAZZA, Roque Antônio. Curso de Direito Constitucional Tributário. $19^{\mathrm{a}}$ ed. São Paulo: Malheiros, 2004. p. 913.

CONCEIÇÃO, Walter Cardoso da. Cofins de sociedades profissionais: conflito com o STF. Gazeta Mercantil, São Paulo, , 16 jun. 2004.

DINIZ, Maria Helena. Dicionário Jurídico. Volume 3. São Paulo: Saraiva, 1998. p. 869.

DINIZ, Maria Helena. Lei de Introdução ao Código Civil Brasileiro Interpretada. São Paulo: Saraiva, 1994. p. 416.

ELALI, André. Cofins e Sociedades de Profissões Regulamentadas. Revista Tributária e de Finanças Públicas. São Paulo, n. ${ }^{\circ}$ 58, p. 62/72, set./out. 2004.

FRANCISCO, José Antônio. A Cofins e as Sociedades Civis de Profissão Regulamentada. Revista de Imposto de Renda. São Paulo, n. ${ }^{\circ}$ 365, p. 25/29, dez. 1997.

GRINOVER, Ada Pellegrini. Coisa julgada tributária. Objeto do processo e limites objetivos da coisa julgada. Relação tributária una e relação 
continuativa. Alcance da Súmula 239 do STF. Não-incidência da posterior declaração de constitucionalidade. A Marcha do Processo. $1^{\mathrm{a}}$ edição. Rio de Janeiro: Forense, 2000. p. 534.

GOMES, Marco Aurélio Carvalho. Da Inexistência de Usurpação de Competência em Sede de Análise da Tributação das Sociedades Civis Prestadoras de Serviço com base na Cofins. A impropriedade da decisão liminar proferida pelo Supremo Tribunal Federal. Revista Tributária e de Finanças Públicas. São Paulo, n. ${ }^{\circ}$ 61, p. 125/135, mar./abr. 2005.

JUNIOR, Nelson Nery; NERY, Rosa Maria de Andrade. Código de Processo Civil Comentado e Legislação Extravagante. $8^{a}$ ed. São Paulo: RT, 2004. p. 2011.

MACHADO, Hugo de Brito. Curso de Direito Tributário. $6^{\mathrm{a}}$ ed. Rio de Janeiro: Forense, 1993. p. 370.

MACHADO, Hugo de Brito. Curso de Direito Tributário. $26^{\mathrm{a}}$ edição, São Paulo, Malheiros Editores, 2005. p. 536.

MARTINS, Ives Gandra da Silva; MARONE, José Ruben. Da Isenção da Cofins Contida no art. 6 ${ }^{\circ}$, II, da LC 70, de 03.12.1991, e do Direito de Recuperação Judicial por via da Compensação dos Valores Indevidamente Recolhidos a esse Título. Revista Tributária e de Finanças Públicas. São Paulo, n. ${ }^{\circ}$ 55, p. 255/281, mar./abr. 2004.

MELLO, Gustavo Miguez. Cofins, Sociedades de Advogados e Aspectos Constitucionais. Revista Dialética de Direito Tributário. São Paulo, n. ${ }^{\circ}$ 114, p. 38/56, mar. 2005 . 
MIRANDA, Pontes de. Comentários ao Código de Processo Civil. Tomo V. $3^{\text {a }}$ edição, Rio de Janeiro: Forense, 1997. p. 364.

MORAES, Alexandre de; FILHO, Manoel Gonçalves Ferreira. Direito Constitucional. $5^{\mathrm{a}}$ ed. São Paulo: Atlas.

MOREIRA, José Carlos Barbosa. Novo Processo Civil Brasileiro. 22 ${ }^{\mathrm{a}}$ edição, Rio de Janeiro: Forense, 2002. p. 345.

NERY, Fernando Loschiavo. A isenção da Cofins das sociedades civis regulamentadas: sua vigência no panorama jurídico hodierno. Disponível em <http://www1.jus.com.br/doutrina/texto.aps?id=5171>. Acesso em 14 set. 2004.

PAULA, Alexandre de. Código de Processo Civil Anotado. Volume II. $3^{\text {a }}$ edição, São Paulo: RT, 1986. p. 565.

PEREIRA, Caio Mário da Silva. Instituições de Direito Civil. Volume I. $18^{\mathrm{a}}$ edição, Rio de Janeiro: Forense, 1995. p. 463.

PEREIRA, Daniel; SANTOS, Gilmara. Governo vai ao STF para reverter isenção da Cofins. Gazeta Mercantil, São Paulo, , 16 nov. 2004.

PINCELLI, Eduardo Pugliese. Súmula 276 do STJ e as reclamações. Gazeta Mercantil, São Paulo, , 07 mar. 2005.

TEIXEIRA, Fernando. TRF isenta bancas do pagamento da Cofins. Valor Econômico, São Paulo, p. 1, 14 set. 2004.

TEIXEIRA, Fernando. TRF mantém Cofins de advogados. Valor Econômico, São Paulo, __, 21 out. 2004. 
TEIXEIRA, Fernando. TRF derruba Cofins de sociedades. Valor Econômico, São Paulo, , 16 jul. 2004.

TEMER, Michel. Elementos de Direito Constitucional. $15^{\mathrm{a}}$ edição. São Paulo: Malheiros, 1999. p. 222.

TRINDADE, Caio de Azevedo. A Isenção da Cofins para as Sociedades Civis de Prestação de Serviços Profissionais, uma Questão Infraconstitucional. Revista Dialética de Direito Tributário. São Paulo, n. ${ }^{\circ}$ 101, p. 51/62, fev. 2004.

SARAIVA, Vicente de Paulo. Expressões Latinas Jurídicas e Forenses. São Paulo, Saraiva, 1999. p. 856.

VELOSO, Zeno. Controle Jurisdicional de Constitucionalidade. $2^{\mathrm{a}}$ ed. Belo Horizonte: Del Rey, 2000. p. 413.

WITT, Marcondes. A COFINS e as Sociedades de Advogados. Revista Dialética de Direito Tributário. São Paulo, n. 96, p. 42/48, set. 2003. 